\title{
NF-KB dependent and independent mechanisms of quartz-induced proinflammatory activation of lung epithelial cells
}

\author{
Damien van Berlo1, Ad M Knaapen2,3, Frederik-Jan van Schooten², Roel PF Schins ${ }^{1}$ and Catrin Albrecht*1
}

\begin{abstract}
In the initiation and progression of pulmonary inflammation, macrophages have classically been considered as a crucial cell type. However, evidence for the role of epithelial type II cells in pulmonary inflammation has been accumulating. In the current study, a combined in vivo and in vitro approach has been employed to investigate the mechanisms of quartz-induced proinflammatory activation of lung epithelial cells. In vivo, enhanced expression of the inflammation- and oxidative stress-related genes $\mathrm{HO}-1$ and iNOS was found on the mRNA level in rat lungs after instillation with DQ12 respirable quartz. Activation of the classical NF-kB pathway in macrophages and type II pneumocytes was indicated by enhanced immunostaining of phospho-IKBa in these specific lung cell types. In vitro, the direct, particle-mediated effect on proinflammatory signalling in a rat lung epithelial (RLE) cell line was compared to the indirect, macrophage product-mediated effect. Treatment with quartz particles induced HO-1 and COX-2 mRNA expression in RLE cells in an NF-KB independent manner. Supernatant from quartz-treated macrophages rapidly activated the NF-KB signalling pathway in RLE cells and markedly induced iNOS mRNA expression up to 2000-fold compared to non-treated control cells. Neutralisation of TNFa and IL-1 $\beta$ in macrophage supernatant did not reduce its ability to elicit NF-kB activation of RLE cells. In addition the effect was not modified by depletion or supplementation of intracellular glutathione.

The results from the current work suggest that although both oxidative stress and NF-KB are likely involved in the inflammatory effects of toxic respirable particles, these phenomena can operate independently on the cellular level. This might have consequences for in vitro particle hazard testing, since by focusing on NF-kB signalling one might neglect alternative inflammatory pathways.
\end{abstract}

\section{Background}

The highly abundant mineral quartz is present in nearly all rocks and minerals to some extent. Quartz can become fractured into very small (respirable) particles in various occupational settings, examples of which are mining, rock drilling, sandblasting, and highway construction. Worldwide, millions of workers are exposed to respirable crystalline silica; it is known for its ability to wreak havoc in the lung at high exposures and is associated with various pathologic conditions. In 1997, the International Agency for Research on Cancer (IARC) upgraded its evaluation of respirable quartz and classified it as a Group 1 human carcinogen [1], which was sup-

\footnotetext{
*Correspondence: catrin.albrecht@uni-duesseldorf.de

${ }^{1}$ Institut für Umweltmedizinische Forschung (IUF) an der Heinrich-HeineUniversität Düsseldorf gGmbH, Germany

Full list of author information is available at the end of the article
}

ported by a later cohort study in nearly 66.000 workers [2]. Quartz exposure can cause silicosis, a severely debilitating, often fatal disease which is characterized by chronic inflammation and persistent fibrosis. Disease progression is irreversible; the situation can deteriorate even when exposure is ceased. Currently, there is no effective treatment for silicosis. Other diseases associated with quartz exposure are COPD, tuberculosis, renal disease and autoimmune disease. A large body of evidence has been established supporting the role of the inflammogenic properties of quartz in the onset of quartzinduced disease. Exposure to high concentrations of respirable crystalline silica is well known to cause progressive fibrosis and lung cancer in rats. In humans, silicosis is associated with an increased risk of lung cancer. Based on chronic inhalation studies in the rat and epide- 
miologic evidence, the ability of quartz to elicit marked and persistent inflammation is believed to be a crucial factor for the development of these severe pathologies [35].

The transcription factor Nuclear Factor-kappa B (NF$\mathrm{kB})$ is pivotal in mediating inflammatory processes in general and is considered as the central regulator activating cells in response to silica [6]. In fact, NF- $\mathrm{kB}$ is also considered important for driving pulmonary toxicity of inflammogenic particles in general [7]. In its dormant state, NF- $\mathrm{B}$, which typically exists as a dimer of the RelA and p50 subunits, resides in the cytosol. Due to its binding to its inhibitor protein $\mathrm{I} \kappa \mathrm{B}$, most commonly $\mathrm{I} \kappa \mathrm{B} \alpha$, it is unable to translocate into the nucleus. In the classical $\mathrm{NF}-\mathrm{kB}$ activation pathway, the inhibitor protein $\mathrm{I} \kappa \mathrm{B} \alpha$ is phosphorylated at serines 32 and 36 by the IKK enzyme complex, ubiquitinated at lysines 21 and 22, and subsequently degraded by the $26 \mathrm{~S}$ proteasome. This unmasks the nuclear localization signal of NF- $\mathrm{KB}$ and liberates it from the nuclear export signal of $\mathrm{I} \kappa \mathrm{B} \alpha$, allowing NF- $\mathrm{B}$ to migrate into the nucleus, where it binds to the DNA, and activates the transcription of many pro-inflammatory genes [7]. The acute inflammatory cytokines Interleukin1 beta (IL-1 $\beta)$ and Tumor Necrosis Factor alpha (TNF $\alpha$ ) are prime examples and potent inducers of NF- $\mathrm{kB}$ themselves [8-11], and are known to be involved in silicosis [12-14]. In addition, reactive oxygen and nitrogen species (ROS and RNS), which are generated in response to silica exposure and have been implicated in its adverse effects [14-17], are known to be capable of activating NF-kB $[18,19]$. Activation of NF-kB by silica has been shown in vivo [20-22], with activation localized to alveolar macrophages and pulmonary epithelial cells in particular $[21,22]$.

In earlier particle toxicology research, the main cell type orchestrating the initial inflammatory response to inhaled particles was thought to be the alveolar macrophage. In the last decades however, evidence for a critical role of the alveolar epithelial type II cell has been building up. Crucially, the Blackwell group showed that in vivo expression of a dominant NF- $\mathrm{kB}$ inhibitor in mouse airway epithelium completely prevented lung inflammation and injury induced by lipopolysaccharide or a constitutively active form of $\mathrm{IKK} \beta$, an enzyme responsible for phosphorylation of the inhibitor of NF- $\kappa B$ (IкB) [23]. These findings show that NF- $\mathrm{kB}$-regulated proinflammatory activation of airway epithelium is essential for the development of pulmonary inflammation. Although macrophages and alveolar lung epithelial cells are two main airway cell types likely to interact with inhaled particles, the contribution of each and the mechanisms involved in their proinflammatory activation are at present not fully known.
The aim of the current study was to investigate the mechanism of proinflammatory activation of lung epithelial cells by quartz. To achieve this, we investigated whether classical NF- $\mathrm{kB}$ pathway activation as well as expression of proinflammatory and oxidative stressinduced genes occurs in vivo in our rat model of quartz exposure. In parallel, we studied the mechanism of NF- $\mathrm{kB}$ activation by quartz particles (Dörentrup Quartz, DQ12) in RLE-6TN rat lung epithelial cells. The direct effect of quartz on RLE cells was compared to its indirect, macrophage product-mediated effect, assessed by treating RLE cells with (particle-free) supernatants of quartztreated NR8383 rat alveolar macrophages.

\section{Methods \\ Reagents}

L-glutamine, Ham's F12 medium, Hanks' balanced salt solution with calcium and magnesium $\left(\mathrm{HBSS}^{(+/+)}\right)$, fetal calf serum (FCS), penicillin/streptavidin solution, glutamine, phosphate buffered saline (PBS), bicinchoninic acid solution, copper(II)sulphate, Horseradish peroxidase (HRP), 5,5-dimethyl-1-pyrroline-N-oxide (DMPO), antimouse-IgG whole protein HRP-conjugated secondary antibody, tubulin antibody, hydrogen peroxide (H2O2), buthionine sulfoximine (BSO), N-acetyl cysteine (NAC) and diaminobenzidine were all obtained from Sigma (Germany). F12-K Nutrient Mixture and Trizol were obtained from Invitrogen (Germany). Protease inhibitors were purchased from Roche Diagnostics $\mathrm{GmbH}$ (Germany) as a Complete ${ }^{\mathrm{mm}}$ cocktail. ECL-reagent/detection system was obtained from GE Healthcare (Germany). Polyclonal antibodies against NF-kB RelA (sc-109) and $\mathrm{I} \kappa \mathrm{B} \alpha(\mathrm{C}-21, \mathrm{sc}-371)$ were supplied by Santa Cruz Biotechnology (USA), antibody against phospho-IkB $\alpha$ (Ser32/36, monoclonal, clone 16A6) was purchased from Cell Signaling Technologies (USA). Recombinant rat IL-1 $\beta$ and TNF $\alpha$, anti-IL-1 $\beta$ neutralizing antibody, anti-TNF $\alpha$ neutralizing antibody and ELISA kits for TNF $\alpha$ and IL-1 $\beta$ were purchased from R\&D Systems (Germany). For immunohistochemical detection secondary biotinylated horse-anti mouse antibody, the streptavidin-biotin-system (Vectastain Elite Kit) and mouse IgG were purchased from Vector Laboratories (USA). Hoechst 33342 was bought from Sigma (Germany) and MFP555 goat antimouse IgG from MoBiTec (Germany). RNeasy mini kit and RNase-free DNase set were provided by Qiagen (Germany). The iScript cDNA Synthesis kit and SYBR@ Green Supermix were bought from Biorad (Germany). NF-kB RelA binding ELISAs and nuclear extraction kits were obtained from Active Motif (Belgium). Isoflurane was bought from Essex Pharma (Germany). All other chemicals were of the highest purity and were supplied by Merck (Germany). RT-PCR primers were designed using 
Primer Express software and ordered from Operon (the Netherlands).

\section{Particles}

Dörentrup quartz (DQ12 batch 6, IUF, Düsseldorf) with a mean diameter of $0.96 \mu \mathrm{m}$ was used as a standard respirable quartz sample to expose animals and treat cell lines. In order to eliminate potential endotoxin contamination, quartz was baked at $220^{\circ} \mathrm{C}$ for $24 \mathrm{~h}$. Immediately before intratracheal (i.t.) instillation of rats, quartz was suspended in phosphate-buffered saline (PBS) at a concentration of $5 \mathrm{mg} / \mathrm{ml}$ and sonicated for $5 \mathrm{~min}$. To treat RLE and NR8383 cells, quartz was suspended in reduced RLE medium (Ham's F12 containing 0.1\% FCS, 1\% $\gamma$-glutamine, $1 \%$ penicillin and $1 \%$ streptomycin), respectively $\mathrm{HBSS}^{(+/+)}$(EPR experiments) or normal NR8383 medium (other experiments, F12-K containing 15\% FCS, $1 \% \gamma$-glutamine, $1 \%$ penicillin and $1 \%$ streptomycin) at a concentration of $1 \mathrm{mg} / \mathrm{ml}$ and was sonicated for $5 \mathrm{~min}$ immediately prior to treatment.

\section{Animals and exposure}

For the in vivo evaluation of NF- $\mathrm{kB}$ activation and mRNA expression, lung tissue and sections were used from an animal study which was previously performed in our lab $[21,24]$. Specific pathogen-free female Wistar rats (Janvier, Le Genest St. Isle, France) were housed and maintained in an accredited on-site testing facility, according to the guidelines of the Society for Laboratory Animals Science (GV-SOLAS). Food and water were available ad libitum. The animals were housed on hardwood bedding in plastic cages in an air-conditioned animal room (23 \pm $2^{\circ} \mathrm{C}$ ) with a regular $12 \mathrm{~h}$ light/dark cycle under SPF conditions. When they reached a weight of 200-250 g (8 weeks old), animals were anaesthetized with isoflurane and i.t. instilled with $2 \mathrm{mg}$ DQ12 quartz (400 $\mu$ l suspension) or the vehicle control only (400 $\mu \mathrm{l}$ PBS) using a laryngoscope. At 3 days after instillation, animals were deeply anesthetized with pentobarbital ( $50 \mathrm{mg} / \mathrm{kg}$ body weight) and sacrificed through exsanguination via the A. abdominalis.

\section{Culture and treatment of Rat Lung Macrophage Cell Line}

NR8383 rat alveolar macrophage cells [25] were seeded in $60 \mathrm{~mm}$ culture dishes at a concentration of $0.5 \times 10^{6}$ per $\mathrm{ml}$ or, specifically for EPR measurements, cells were seeded in 24-wells plates at the same concentration. Cells were cultivated in Ham's F12K medium $/ 15 \%$ fetal calf serum (FCS) $/ 1 \%$ penicillin $/ 1 \%$ streptomycin $/ 1 \%$ glutamine for 3 days until they reached $60 \%$ confluence. Culture and treatments took place at $37^{\circ} \mathrm{C}$ and $5 \% \mathrm{CO}_{2}$. Subsequently, cells were treated with 10,40 or $80 \mu \mathrm{g} / \mathrm{cm}^{2}$ quartz for $0.5-24 \mathrm{~h}$ as indicated for each specific experiment. Control cells received an equal volume of fresh
NR8383 medium. After treatment, supernatants were harvested, either for direct measurement of ROS and cytokines using EPR and ELISA respectively, or for treatment of RLE cells. Obtained supernatants to be used for RLE treatment and ELISA were spun at low speed (200 g for $5 \mathrm{~min}$ ) to remove non-adherent cells, and in order to remove cell debris and particles, they were spun once more at $18000 \mathrm{~g}$ for $5 \mathrm{~min}$. Supernatants destined for EPR analysis were measured directly upon harvest.

\section{Culture and treatment of Rat Lung Epithelial Cell Line}

Immortalized RLE cells [26] were seeded in $60 \mathrm{~mm}$ or 100 $\mathrm{mm}$ culture dishes at a concentration of $3 \times 10^{4}$ cells per $\mathrm{cm}^{2}$ and cultivated in 2 or $6 \mathrm{ml}$ (for $60 \mathrm{~mm}$ and $100 \mathrm{~mm}$ plates, respectively) Ham's F12 medium containing 5\% FCS $/ 1 \%$ penicillin $/ 1 \%$ streptomycin $/ 1 \%$ glutamine. At $90 \%$ confluence, medium was discarded and replaced by serum-reduced medium containing $0.1 \%$ FCS for $24 \mathrm{~h}$ for cell synchronization. Culture and treatments took place at $37^{\circ} \mathrm{C}$ and $5 \% \mathrm{CO} 2$.

Cells were treated with quartz particles at concentrations of 10,40 or $80 \mu \mathrm{g} / \mathrm{cm}^{2}$ for $0.5-24 \mathrm{~h}$ as indicated. To compare the direct effects of quartz to the indirect (macrophage-mediated) effects, cells were additionally treated with 1:6 diluted (in serum-reduced RLE medium) supernatant of quartz-treated $\left(10,40\right.$ or $\left.80 \mu \mathrm{g} / \mathrm{cm}^{2}, 1-24 \mathrm{~h}\right)$ or non-treated control macrophages (Q-MS and c-MS, respectively). Based on pilot investigations, the highest dilution that still elicited a clear activation of the NF- $\mathrm{kB}$ pathway was selected. Control cells received fresh medium, for a period equal to the longest treatment. NF$\mathrm{\kappa B}$ and expression of the investigated genes were not induced by addition of fresh medium, at any time point up to $24 \mathrm{~h}$ (data not shown).

To investigate the potential of acute inflammatory cytokines and ROS to induce NF-kB activation in RLE cells, cells were treated with recombinant rat TNF $\alpha$ or IL$1 \beta$ at concentrations of $0.1 \mathrm{up}$ to $10 \mathrm{ng} / \mathrm{ml}$ as well as with hydrogen peroxide $\left(\mathrm{H}_{2} \mathrm{O}_{2}\right)$ at a concentration of $50 \mu \mathrm{M}$ for up to 2 hours. For the latter treatment, medium was taken off and was replaced by HBSS.

In order to inhibit cytokine activity, IL-1 $\beta$ and TNF $\alpha$ were inactivated using neutralizing antibodies. In a first step, effectiveness of inhibition was investigated by pretreating recombinant TNF $\alpha$ and IL-1 $\beta$ diluted in macrophage medium for $1 \mathrm{~h}$ with neutralizing antibody at various concentrations. Cells were then treated with this mixture containing $1 \mathrm{ng} / \mathrm{ml} \mathrm{TNF} \alpha$ or $0.5-1 \mathrm{ng} / \mathrm{ml} \mathrm{IL-} 1 \beta$, the lowest concentrations found to induce a clearly visible degradation of IкB $\alpha$ as observed by Western blot. Optimal neutralizing antibody concentrations completely inhibiting cytokine-induced IкB $\alpha$ degradation were found to be $2.5 \mu \mathrm{g} / \mathrm{ml}$ for anti-IL- $1 \beta$ and $5 \mu \mathrm{g} / \mathrm{ml}$ for antiTNF $\alpha$. 
Next, macrophage supernatants were pre-treated with either neutralizing antibody, or both simultaneously $(2.5$ $\mu \mathrm{g} / \mathrm{ml}$ anti-IL- $1 \beta$ and $5 \mu \mathrm{g} / \mathrm{ml}$ anti-TNF $\alpha$.), to inhibit cytokine activity. These conditioned media were then used to treat RLE cells.

To assess the influence of the intracellular redox status, intracellular glutathione was either depleted by incubating cells with $0.1 \mathrm{mM}$ buthionine sulfoximine (BSO) for $24 \mathrm{~h}$, or supplemented through treatment with $1 \mathrm{mM}$ NAC for $2 \mathrm{~h}$. BSO is a known inhibitor of glutathione synthesis, while NAC acts as a precursor for glutathione and provides the amino acid whose availability is ratelimiting for glutathione synthesis.

\section{Lung fixation and immunohistochemistry for phosphorylated (Ser32/36) IкBa}

Lungs of 5 quartz-exposed and 5 control animals were instilled in situ with 4\% paraformaldehyde/PBS (pH 7.4) under atmospheric pressure, removed, fixed in the same solution for at least $12 \mathrm{~h}$, dehydrated, and paraffin embedded. After deparaffinization of $3 \mu \mathrm{m}$ - lung sections with Xylene $(2 \times$ for $10 \mathrm{~min})$, slides were washed successively for $10 \mathrm{~min}$ in acetone, acetone-TBS (1:1), and TBS. Subsequently, endogenous peroxidases were inactivated with $0.3 \%$ hydrogen peroxide for $30 \mathrm{~min}$. After washing with TBS, sections were permeabilized in citrate buffer (pH 6.0) by microwave treatment and were washed again with TBS. Non-specific binding sites were blocked with normal horse serum (1:65) for $1 \mathrm{~h}$, followed by incubation with a mouse monoclonal antibody against phosphoIкB $\alpha(S e r 32 / 36)$. To allow for detection, slides were then incubated with a secondary biotinylated horse antimouse antibody (1:200) followed by the streptavidin-biotin-complex according to the manufacturer's protocol. Diaminobenzidine (DAB) was used as a substrate, and the slides were counter-stained with hematoxylin. As a negative control, serial sections were incubated with mouse IgG instead of the primary antibody at the same IgG concentration. Slides were analyzed using a light microscope (Olympus BX60).

\section{Quantitative RT-PCR analysis of gene expression in whole rat lung homogenate or RLE cells}

Lungs of 3 quartz- and 3 saline-instilled animals as well as RLE cells were homogenized in Trizol. Subsequently RNA was extracted according to the manufacturer's instructions. The RNeasy mini kit coupled to DNAse treatment was used to purify total RNA from salts and residual DNA. Quantity and purity of RNA were evaluated using spectrophotometry at 230, 260, 280, and 320 nm. cDNA was synthesized using the iScript cDNA Synthesis kit, starting from $0.5 \mu \mathrm{g}$ of RNA. cDNA was diluted $15 \times$ in water before use. PCR primers for rat HO-1, iNOS, COX-2 and the housekeeping gene HPRT were designed using Primer Express software (Applied Biosystems). Primer sequences for HO-1 were $5^{\prime}$-GGG AAG GCC TGG CTT TTTT-3' (forward) and 5'-CAC GAT AGA GCT GTT TGA ACT TGGT-3' (reverse), for iNOS 5'-AGG AGA GAG ATC CGG TTC ACA GT-3' (forward) and 5'-ACC TTC CGC ATT AGC ACA GAA-3' (reverse), for COX-2 5'-GCA CAA ATA TGA TGT TCG CAT TCT-3' (forward) and 5'-GAA CCC AGG TCC TCG CTT CT-3' (reverse), and for HPRT 5'-GCC CTT GAC TAT AAT GAG CAC TTC A-3' (forward) and 5'-TCT TTT AGG CTT TGT ACT TGG CTT TT-3' (reverse). qRT-PCR was performed with a MyiQ Single Color real time PCR detection system (BioRad) using SYBR@ Green Supermix, $5 \mu \mathrm{l}$ diluted cDNA, and $2.5 \mu \mathrm{l}$ of $0.3 \mu \mathrm{M}$ forward and reverse primer in a total volume of $25 \mu \mathrm{l}$. PCR was conducted as follows: a denaturation step at $95^{\circ} \mathrm{C}$ for 3 min was followed by 40 cycles at $95^{\circ} \mathrm{C}$ (15 seconds) and $60^{\circ} \mathrm{C}$ (45 seconds). After PCR, a melt curve $\left(60-95^{\circ} \mathrm{C}\right)$ was generated for product identification and purity. PCR efficiency of all four primer sets, as assessed by the use of cDNA dilution curves, was $90-100 \%$. Data were analyzed using the MyiQ Software system (BioRad) and were expressed as relative gene expression (fold increase) using the 2- $\Delta \mathrm{Ct}$ method [27].

\section{Immunocytochemistry for RelA in RLE cells}

RLE cells were cultured to near confluence on 4-chamber culture slides (BD Falcon) for the immunocytochemical evaluation of the subcellular localization of RelA. After treatment, cells were washed in TBS, followed by incubation with $0.3 \%$ hydrogen peroxide for $30 \mathrm{~min}$. After permeabilisation with $0.1 \%$ TritonX-100 for $5 \mathrm{~min}$, nonspecific binding sites were blocked with normal goat serum (1:65) for $1 \mathrm{~h}$. For detection, cells were incubated with a rabbit polyclonal antibody against NF- $\mathrm{kB}$ RelA overnight at $4^{\circ} \mathrm{C}$ followed by a secondary goat anti-rabbit antibody (MFP555, 1:200). Cells were counter-stained with Hoechst $33342(1 \mu \mathrm{g} / \mathrm{ml})$. In order to control for unspecific staining, cells were incubated with rabbit IgG, instead of the primary antibody, at the same IgG concentration. Cells were analyzed using a fluorescence microscope (Olympus BX60) at an original magnification of $\times 1000$.

\section{NF-KB RelA binding activity assay}

To investigate DNA binding activity of NF-kB RelA in RLE nuclear extracts, an ELISA-based DNA binding activity assay [28] was performed.

Nuclear fractions of RLE cells were prepared using a nuclear extraction kit. To perform the assay, $5 \mu \mathrm{g}$ of nuclear extract was transferred to each well and the assay was performed according to the manufacturer's recommendations. As a positive control, $2.5 \mu \mathrm{g}$ Jurkat cell nuclear extract was used (supplied in the kit). Absorbance 
was read at $450 \mathrm{~nm}$, while $650 \mathrm{~nm}$ was used as the reference wavelength.

\section{Western blotting}

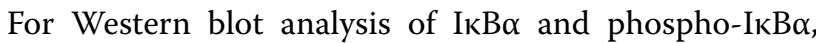
whole cell extracts were prepared. RLE cells were harvested by gentle scraping and then lysed by $30 \mathrm{~min}$ incubation in $200 \mu$ l RIPA buffer (1\% NP-40, 0.5\% sodium deoxycholate, $0.1 \%$ sodium dodecyl sulfate in PBS) containing freshly added protease inhibitors at $4 \mathrm{C}$. Subsequently, they were centrifuged for $20 \mathrm{~min}$ at $15000 \mathrm{G}$ and 4 C.

In the resulting supernatant, protein concentrations were determined using the bicinchoninic acid (BCA) assay, equal amounts $(20 \mu \mathrm{g})$ were electrophoresed through $10 \%$ sodium dodecyl sulfate (SDS)-polyacrylamide gels, and transferred onto nitrocellulose membranes. Non-specific protein binding was blocked with $5 \%$ dried milk powder and $0.1 \%$ Tween-20 in PBS. Immunolocalization of $I \kappa B \alpha$ protein was performed using a polyclonal antibody $(1: 1000)$ and an anti-rabbit-IgG whole protein HRP-conjugated secondary antibody (1:3000). To detect ІкB $\alpha$ phosphorylated at serine 32 and/or 36 , a monoclonal antibody was used (1:2000) in combination with an anti-mouse-IgG whole protein HRP-conjugated secondary antibody (1:2000). To normalize total protein amounts, blots were re-probed with an antibody against $\beta$-tubulin (1:5000) and a secondary anti-mouse-IgG whole protein HRP-conjugated antibody (1:5000). Band formation was visualized using an ECL Plus reagent/ detection system. Quantification was performed by computer-assisted densitometry scanning using a documentation system with appropriate software (Gel-doc, BioRad, Germany). Shown blots are representative for multiple experiments.

\section{ELISA}

The presence of IL-1 $\beta$ and TNF $\alpha$ in macrophage media was quantified using ELISAs according to the manufacturer's recommendations (R\&D Systems). TNF $\alpha$ and IL$1 \beta$ concentrations were expressed in $\mathrm{pg} / \mathrm{ml}$ and supernatant of non-treated cells was used as control.

\section{Electron paramagnetic resonance (EPR)}

For the assessment of the quartz-induced generation of .OH by alveolar macrophages, NR8383 cells were cultured in 24-wells plates for 3 days. Before quartz treatment, cells were incubated for 30 min in HBSS containing calcium and magnesium $\left(\mathrm{HBSS}^{(+/+)}\right)$. NR8383 cells were treated with freshly sonicated quartz at a concentration of 10 or $40 \mu \mathrm{g} / \mathrm{cm}^{2}$ for $1 \mathrm{up}$ to $3 \mathrm{~h}$ at $37^{\circ} \mathrm{C}$ in the presence of $0.11 \mathrm{M}$ 5,5-dimethyl-1-pyrroline-N-oxide (DMPO). Supernatant was transferred to a $100 \mu \mathrm{l}$ glass capillary and $\cdot \mathrm{OH}$ generation was measured using a Miniscope
MS200 EPR spectrometer (Magnetech, Berlin, Germany). EPR spectra were recorded at room temperature using the following instrumental conditions: Magnetic field: 3,360 G; sweep width: $100 \mathrm{G}$; scan time: $30 \mathrm{~s}$; number of scans: 3; modulation amplitude: $1,800 \mathrm{G}$. The EPR signal, generated in the form of a DMPO-OH peak quartet was quantified; the amplitudes were averaged and expressed in arbitrary units (A.U.).

\section{Glutathione assay}

To determine the efficiency of glutathione depletion or supplementation using BSO and NAC respectively, the intracellular total glutathione content was measured using the method developed by Tietze [29].

RLE cells were cultured in 6-well plates for 3 days until confluency was reached. At that point they were harvested by incubating cells with $500 \mu \mathrm{l}$ trypsin-EDTA per well for $5 \mathrm{~min}$ at $37^{\circ} \mathrm{C}$. After $5 \mathrm{~min}, 1 \mathrm{ml}$ ice-cold culture medium was added. Next, cells were spun at $140 \mathrm{G}$ for 5 $\min$ at $4^{\circ} \mathrm{C}$ and washed twice with $1 \mathrm{ml}$ ice-cold PBS. Icecold extraction buffer $(0.1 \%$ Triton/0.6\% Sulfosalicylic acid in KPE buffer) was added to the cell pellet, which was subsequently homogenized using a Teflon pestle, and alternatingly vortexed and sonicated 3 times for 20 respectively $30 \mathrm{sec}$. Cell debris were collected by centrifugation at $3500 \mathrm{G}$ for $5 \mathrm{~min}$ at $4^{\circ} \mathrm{C}$ and the supernatant was kept on ice until analysis.

Briefly, $20 \mu \mathrm{l}$ of each sample was mixed with 5,5'Dithiobis(2-nitrobenzoic acid) (DTNB) and glutathione reductase, and GSSG (reduced glutathione) was allowed to be converted to the oxidized form GSH for $30 \mathrm{sec}$, after which $\beta$-NADPH was added. The rate of change in absorbance was measured at $412 \mathrm{~nm}$. The calculated glutathione concentration was corrected for the total protein concentration and expressed as \% of control.

\section{Statistical evaluation}

Data are expressed as mean \pm SD, unless stated otherwise. Student's T-test was used to evaluate mRNA expression in the lungs of quartz versus saline exposed rats. A difference was considered to be statistically significant when $\mathrm{p}<0.05$. All in vitro experiments represent at least two independent experiments. NF- $\mathrm{KB}$ activation (as measured by ELISA), production of TNF $\alpha, \mathrm{IL}-1 \beta$ and ROS as well as mRNA expression changes were evaluated by ANOVA with Dunnett's posthoc comparison method. Effects are indicated at $\mathrm{p}<0.05$ and $\mathrm{p}<0.01$.

\section{Results}

\section{$\mathrm{NF}-\mathrm{KB}$ is activated in vivo in rats after quartz exposure}

To determine the effects of respirable quartz exposure on in vivo activation of the classical NF- $\mathrm{kB}$ pathway, lung tissue sections of quartz-exposed rats were analyzed for Ser32/36-phosphorylated IкB $\alpha$ by immunohistochemis- 
try. Moreover, we investigated gene expression changes of the NF-kB-regulated genes iNOS and COX-2, as well as the oxidative stress marker heme oxygenase-1 (HO-1) in whole lung tissue homogenates obtained from quartzinstilled animals and control animals by qRT-PCR. Representative pictures of lung sections stained for Ser32/36-

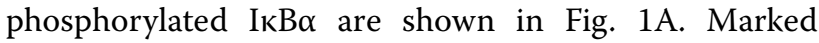
immunoreactivity was observed in both alveolar macrophages and alveolar epithelial type II cells. In contrast, Ser32/36-phosphorylated IкB $\alpha$ was not observed in tissue sections of saline-instilled lungs. In the quartzinstilled group significantly higher mRNA expression of iNOS and HO-1 was found, as is shown in Fig. 1B. The mRNA expression of COX-2 was also slightly increased but this did not reach statistical significance (Fig. 1B).

\section{Mediators released from quartz-treated macrophages are stronger activators of NF-KB in rat lung epithelial cells than quartz particles}

To compare NF- $\mathrm{kB}$ activation induced by quartz particles (direct effect) or by mediators released from quartztreated macrophages (indirect, macrophage-mediated effect) in RLE cells, NF-kB activation was determined on four levels: Nuclear translocation of the RelA subunit of NF- $\mathrm{kB}$ was visualised by immunocytochemical analysis, RelA NF- $\kappa \mathrm{B}$ binding activity was measured using a binding activity assay and finally $\mathrm{I} \kappa \mathrm{B} \alpha$ phosphorylation and degradation were investigated by Western blotting. The latter two endpoints are specific indicators of the classical NF- $\mathrm{kB}$ activation pathway. Supernatants from quartztreated NR8383 macrophages (Q-MS) were found to elicit marked RelA nuclear translocation in RLE cells, whereas treatment with quartz and supernatants from untreated control macrophages (c-MS) did not (Fig. 2A). Q-MS also increased the DNA binding affinity of RelA in RLE nuclear extracts, in contrast to quartz treatment (Fig. 2B). Finally, Q-MS were shown to induce a fast and strong degradation of $\mathrm{I}_{\kappa} \mathrm{B} \alpha$, preceded by phosphorylation (Fig. $3 \mathrm{~B})$. In contrast, direct quartz treatment induced only a mild reduction of the steady-state level of IkB $\alpha$ after a 24 $\mathrm{h}$ treatment with $40 \mu \mathrm{g} / \mathrm{cm}^{2}$ quartz, in the absence of any detectable $\mathrm{I} \kappa \mathrm{B} \alpha$ phosphorylation (Fig. 3A). Replacing medium only for up to $24 \mathrm{~h}$ did not result in detectable NF- $\mathrm{kB}$ activation (data not shown). The fast phosphorylation (5 $\mathrm{min})$ and subsequent degradation of $\mathrm{I} \kappa \mathrm{B} \alpha(10$ min) induced by Q-MS was followed by a rapid restoration (30 to $60 \mathrm{~min}$ ) due to its de novo synthesis (Fig. 3B).

By treating NR8383 macrophages with quartz for periods of 1 up to $24 \mathrm{~h}$, we found that supernatants obtained from cells treated for at least $4 \mathrm{~h}$ with quartz were able to activate NF- $\mathrm{B}$ in RLE cells, as observed by $\mathrm{I} \kappa \mathrm{B} \alpha$ phosphorylation and degradation (Fig. 3C). The strongest effects are observed with Q-MS from macrophages treated for 12 or $24 \mathrm{~h}$. Additionally, we observed that the
NF- $\mathrm{kB}$ activating properties can only be attributed to conditioned media obtained from macrophages that were treated with high quartz concentrations (i.e. 40 or $80 \mu \mathrm{g}$ / $\mathrm{cm}^{2}$ ) (Fig. 3D). When taken together, our data suggest that in quartz exposed lungs, NF- $\mathrm{kB}$ activation in lung epithelium occurs predominantly via indirect mechanisms, mediated by macrophage products, rather than directly through the quartz particles themselves.

\section{Macrophages produce ROS and acute inflammatory cytokines in response to quartz in a time- and dose- dependent manner}

The ability of quartz to elicit ROS production from NR8383 cells was determined by EPR coupled to DMPO spin trapping. Quartz was found to induce ROS generation from the NR8383 cells in both a dose- and timedependent manner (Fig. 4A). To investigate the role of the inflammatory cytokines IL- $1 \beta$ and TNF $\alpha$ in macrophagemediated NF- $\kappa B$ pathway activation in the RLE cells, their presence in Q-MS was measured by ELISA. Treatment of NR8383 cells with $40 \mu \mathrm{g} / \mathrm{cm}^{2}$ quartz elicited a marked release of TNF $\alpha$ and IL-1 $\beta$ (Fig. 4B), reaching a maximum value of around $0.3 \mathrm{ng} / \mathrm{ml}$ for both cytokines after $12-24 \mathrm{~h}$ of treatment.

\section{Neutralizing antibodies are capable of fully blocking TNFa- and IL-1 $\beta$-induced NF-KB activation, but do not reduce $Q-$ MS -induced activation of NF-KB}

In Fig.5A, the ability of anti-TNF $\alpha$ and anti-IL-1 $\beta$ neutralizing antibodies to block activation of NF- $\mathrm{B}$ in RLE cells by their respective cytokine targets is demonstrated by Western blot analysis of $I \kappa B \alpha$. The same concentration of neutralizing antibodies shown to abrogate TNF $\alpha$ - and IL-1 $\beta$-induced NF- $\mathrm{KB}$ activation in RLE cells was then used to pre-treat Q-MS, before addition to RLE cells. QMS contained markedly less TNF $\alpha$ and IL-1 $\beta$ than was used for the treatments with each respective cytokine, therefore the neutralising antibody concentrations should be more than sufficient. No visible decrease in the NF$\mathrm{\kappa B}$-activating potential could be observed after pretreatment with either antibody (Fig. 5B). To account for compensatory effects, a mixture of both neutralizing antibodies was also used as Q-MS pre-treatment. However, even blocking the activity of both cytokines did not result in an inhibition of $\mathrm{I}_{\kappa} \mathrm{B} \alpha$ Ser32/36 phosphorylation and $\mathrm{I} \kappa \mathrm{B} \alpha$ degradation or RelA nuclear translocation (Fig. $5 \mathrm{C})$. These results suggest that neither TNF $\alpha$ nor IL-1 $\beta$ do play an essential role in NF- $\mathrm{kB}$ activation in lung epithelial cells induced by macrophage products.

\section{Modulation of the intracellular glutathione level does not affect Q-MS-induced activation of NF-KB}

To study the influence of the intracellular redox-status on Q-MS-induced NF-kB activation, glutathione was 


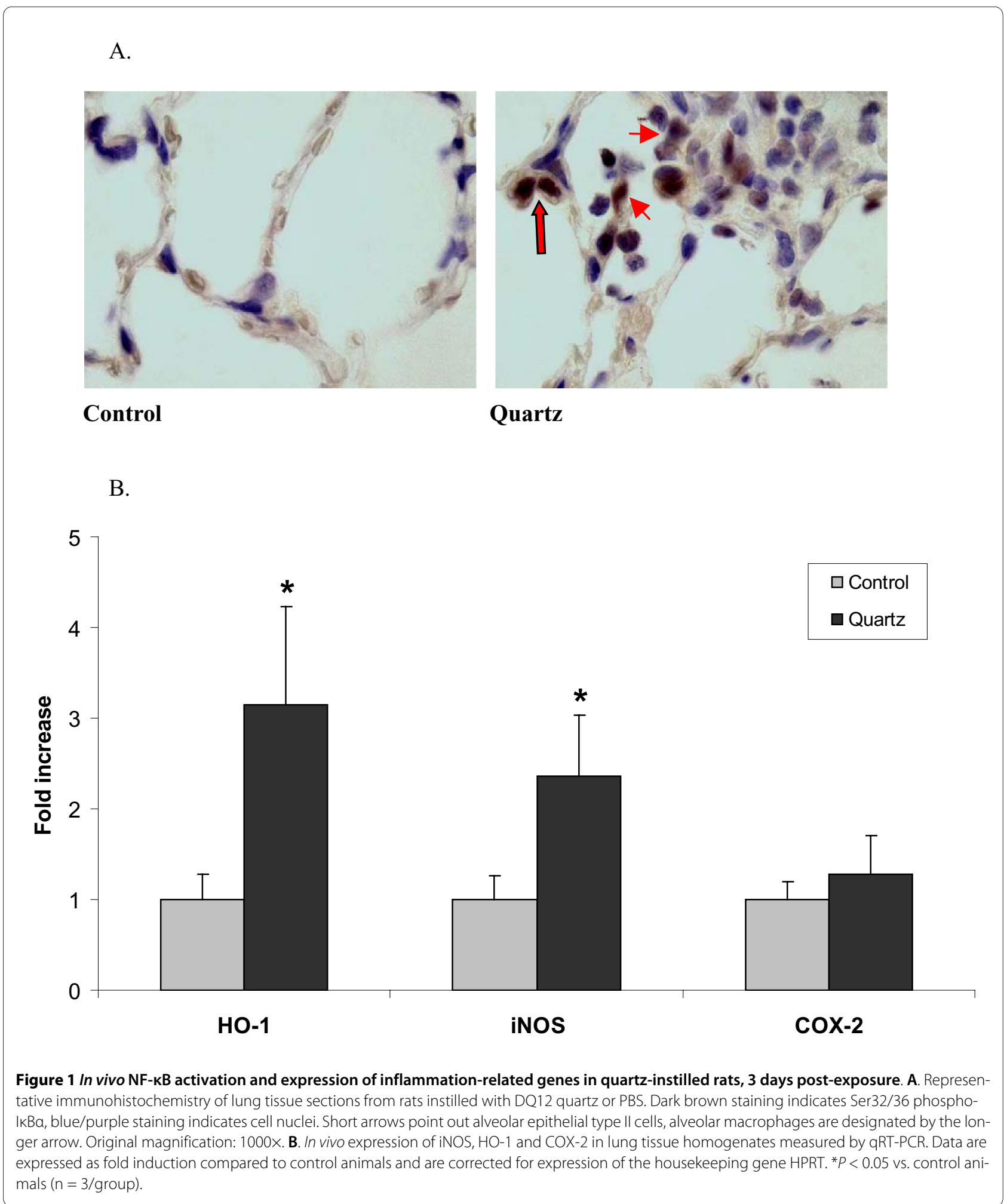

depleted in RLE cells using buthionine sulfoximine (BSO), or supplemented by NAC treatment. Treatment of RLE cells with BSO was found to cause a dose-dependent depletion of intracellular glutathione to a minimum of $5 \%$ of the control level whereas treatment with the glutathi- one precursor NAC was found to enhance intracellular glutathione levels up to a maximum of $133 \%$ (data not shown). Concentrations inducing a maximal effect (0.1 $\mathrm{mM}$ BSO and $1 \mathrm{mM} \mathrm{NAC)}$ were used in subsequent experiments. These experiments showed that, irrespec- 
A.
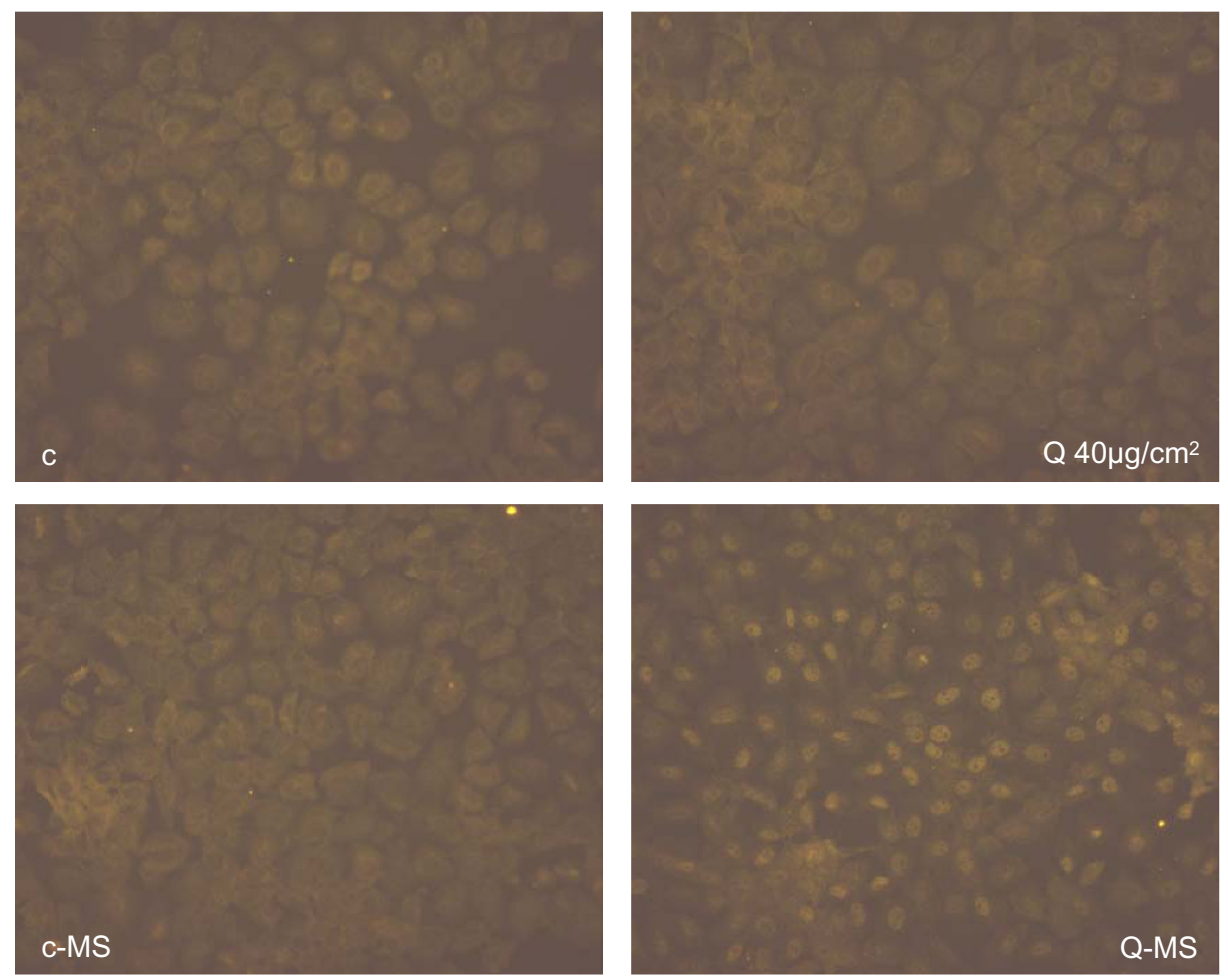

B.

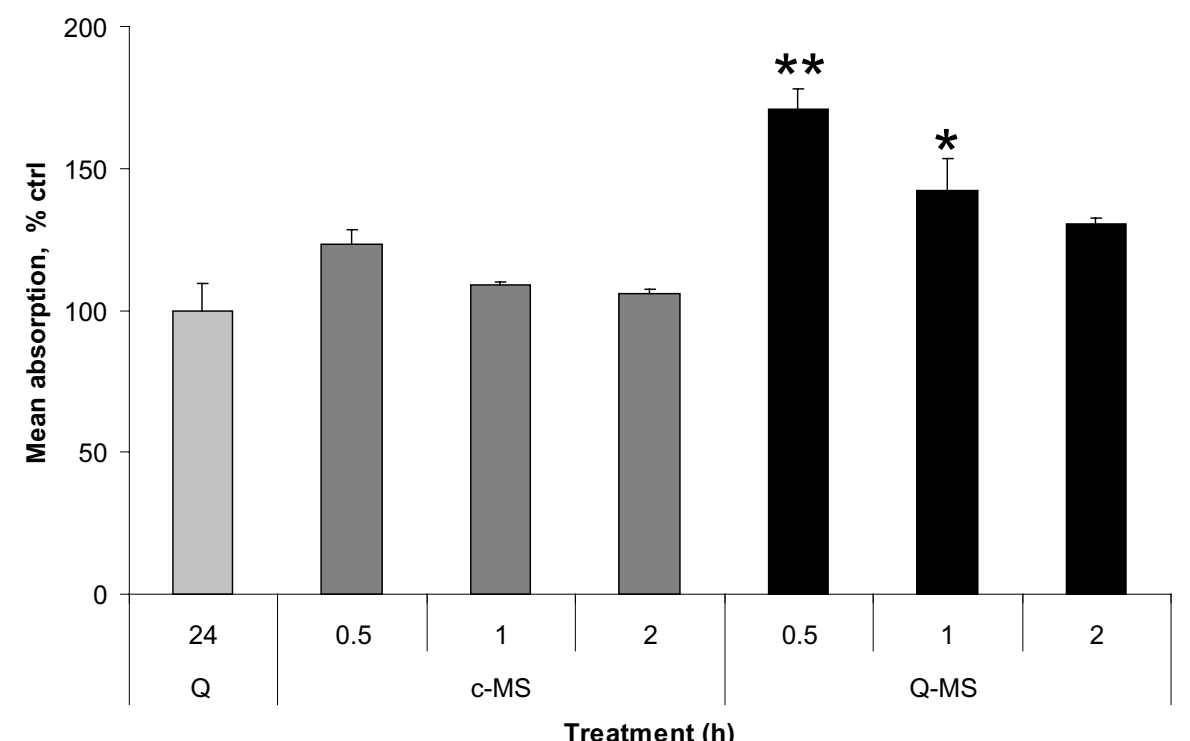

Figure 2 Effects of quartz and supernatants from quartz-treated macrophages on epithelial NF-kB pathway activation A. Immunocytochemistry of RelA nuclear translocation in RLE cells treated with supernatants from quartz-treated macrophages (Q-MS), untreated control macrophages (CMS), or after direct treatment with quartz (Q). These are compared with untreated control cells (c). Cells were treated for 30 min with Q-MS and c-MS or quartz. Orange staining indicates the presence of the RelA subunit of the NF-KB complex. Original magnification: 400X. B. DNA binding activity of nuclear extracts from RLE cells treated with $40 \mu \mathrm{g} / \mathrm{cm}^{2}$ quartz for $24 \mathrm{~h}(\mathrm{Q})$, or with supernatants from untreated (c-MS) or quartz-treated (Q-MS) macrophages for 30, 60 or $120 \mathrm{~min}$. Data are expressed as percentage of non-treated controls. ${ }^{*} P<0.05$ and ${ }^{* *} P<0.01$ vs. control (100\%). 
A.

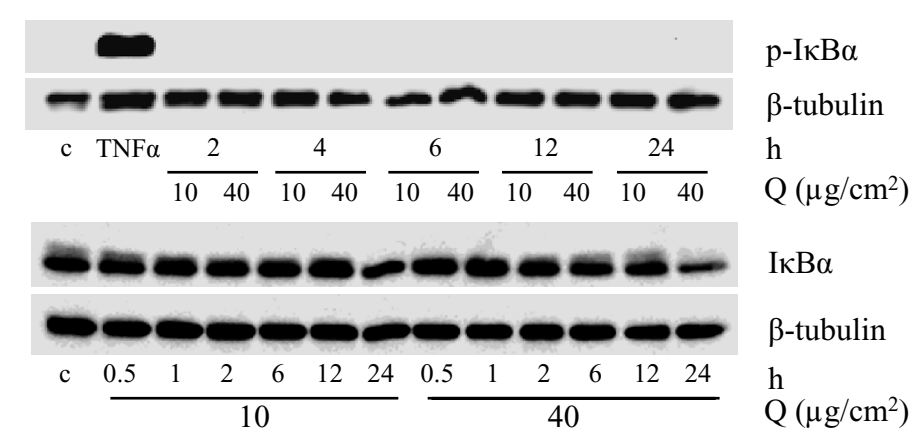

B.

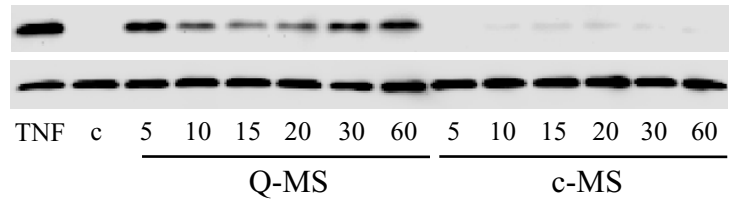

$\mathrm{p}-\mathrm{I \kappa} \mathrm{B} \alpha$

$\beta$-tubulin

$\min$

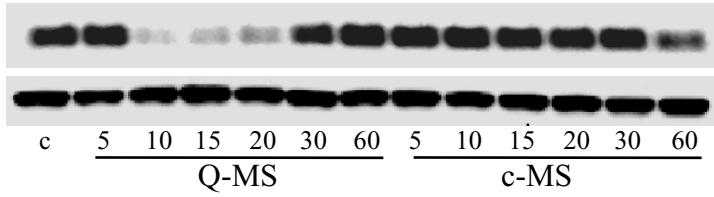

$\mathrm{I} \kappa \mathrm{B} \alpha$

$\beta$-tubulin

$\min$

C.

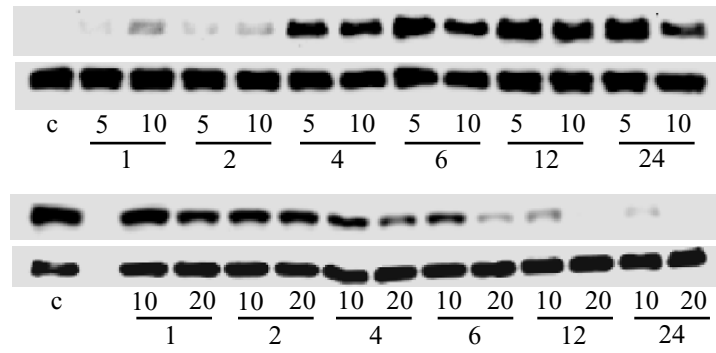

$\mathrm{p}-\mathrm{I} \kappa \mathrm{B} \alpha$

$\beta$-tubulin

Q-MS RLE (min)

Q NR (h)

$\mathrm{I} \kappa \mathrm{B} \alpha$

$\beta$-tubulin

Q-MS RLE (min)

Q NR (h)

D.

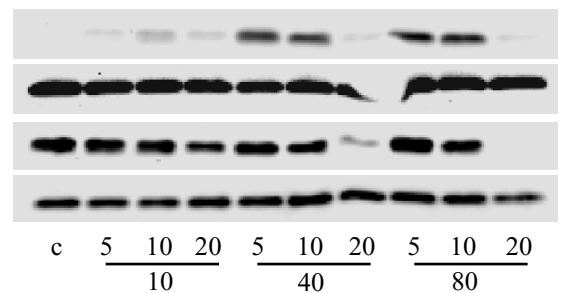

$\mathrm{p}-\mathrm{I} \kappa \mathrm{B} \alpha$

$\beta$-tubulin

$\mathrm{I} \kappa \mathrm{B} \alpha$

$\beta$-tubulin

Q-MS RLE (min)

Q NR $(\mu \mathrm{g} / \mathrm{cm} 2)$

Figure $3 \mathrm{NF-KB}$ activation in RLE cells by quartz particles compared to indirect, macrophage mediator-induced NF-KB activation. A Western blot analysis of Ser32/36 phosphorylation and IkBa degradation in whole cell extracts of RLE cells treated with 10 or $40 \mu \mathrm{g} / \mathrm{cm}^{2}$ quartz (Q)for 0.5 to 24 h. TNFa (10 ng/ml, $10 \mathrm{~min}$ ) was used as positive control for Ser32/36 phosphorylation ( $c=$ untreated cells). $\beta$-tubulin is used as loading control. B Ser32/36-phosphorylation and IKBa degradation in RLE cells treated for 5 to 60 min with supernatants of quartz-treated (Q-MS) or untreated (c-MS) NR8383 cells ( $c=$ untreated cells). Macrophages were treated with $40 \mu \mathrm{g} / \mathrm{cm}^{2}$ DQ12 or medium for $24 \mathrm{~h}$. TNFa (10 ng/ml, $\left.10 \mathrm{~min}\right)$ was used as positive control for Ser32/36 phosphorylation. $\beta$-tubulin served as loading control. C. IkBa phosphorylation and degradation in RLE cells treated for 5 to 20 min with supernatants harvested from macrophages that were previously treated with $40 \mu \mathrm{g} / \mathrm{cm}^{2}$ quartz for 1 to $24 \mathrm{~h}$ ( $c=$ untreated cells; Q-MSRLE= treatment time for RLE cells with the macrophage supernatants; $Q$ NR = treatment time for NR8383 macrophages with quartz). $\beta$-tubulin was used as loading control. D. IKBa phosphorylation and degradation in RLE cells treated with supernatants harvested from NR8383 macrophages treated for $24 \mathrm{~h}$ with 10,40 or $80 \mu \mathrm{g} / \mathrm{cm}^{2}$ quartz ( $c=$ untreated cells; $Q-M S R L E=$ treatment time for RLE cells with the macrophage supernatants; $Q N R=$ treatment concentration for NR8383 macrophages with quartz). As loading control, blots were reprobed with a $\beta$-tubulin-antibody. 
A.

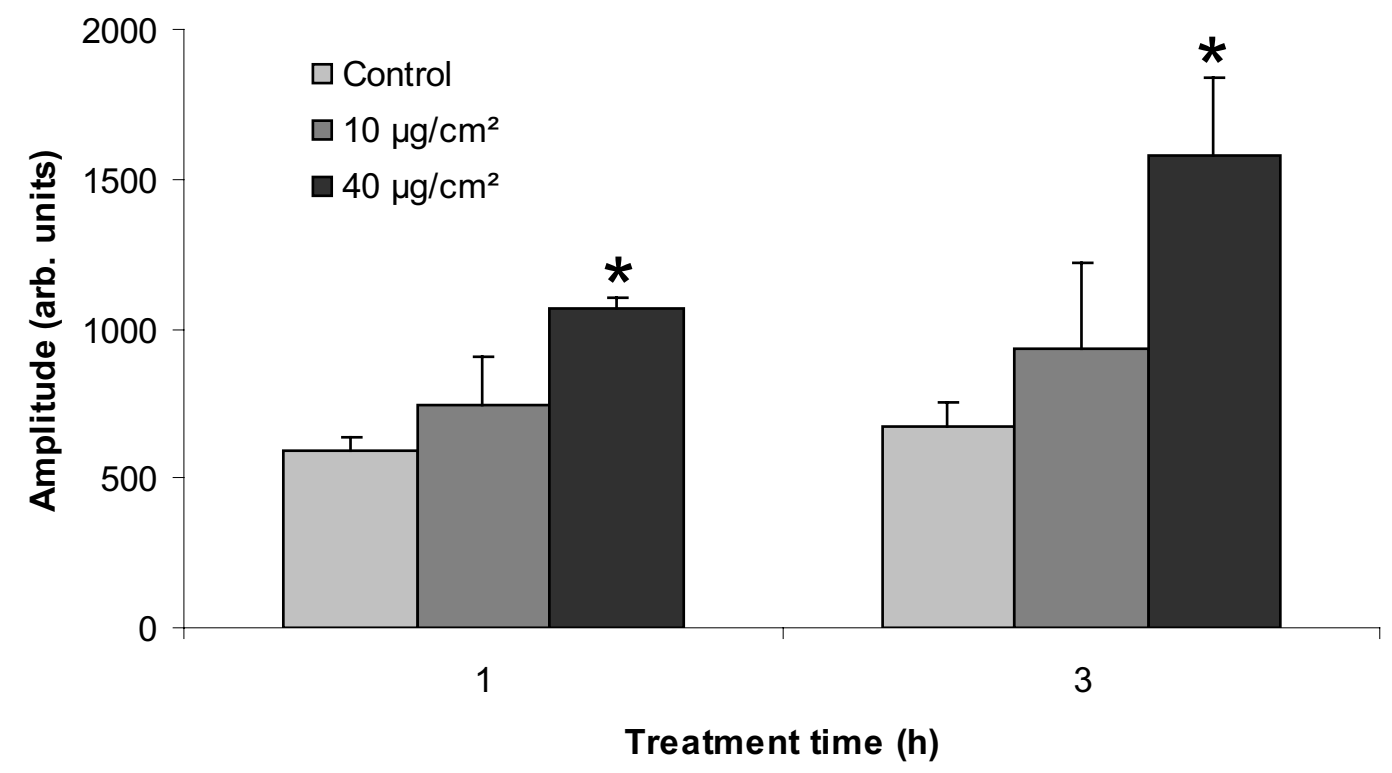

B.

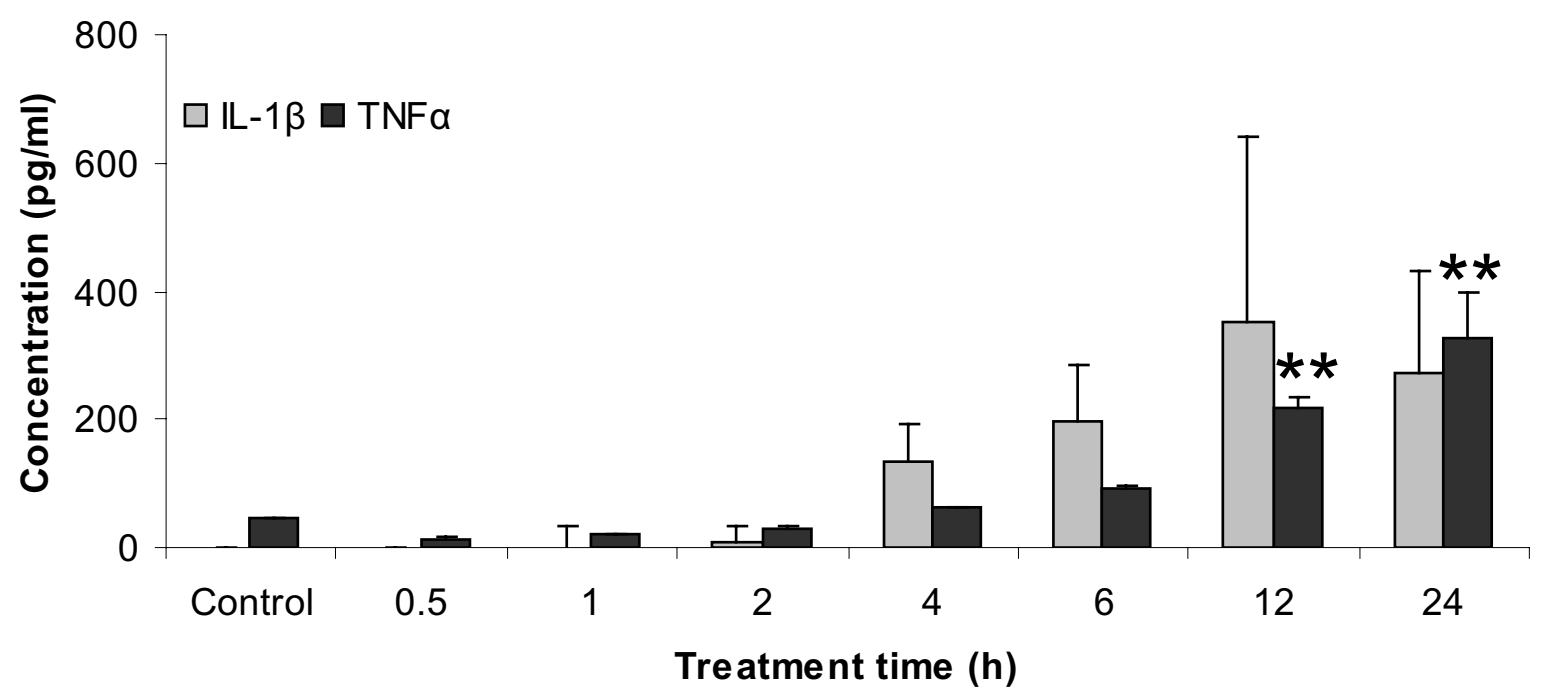

Figure 4 Release of ROS, IL-1 $\beta$ and TNFa by quartz-treated NR8383 macrophages. A. Reactive oxygen species (ROS) formation by NR8383 macrophages in response to quartz treatment for 1 and $3 \mathrm{~h}$ at concentrations of 10 and $40 \mu \mathrm{g} / \mathrm{cm}^{2}$, measured by EPR spectroscopy in combination with the spin trap DMPO. The mean amplitude of the four peaks representing DMPO-OH adducts is expressed in arbitrary units. B. IL-1 $\beta$ and TNFa concentrations (pg/ml) measured by ELISA in non-diluted supernatants of NR8383 macrophages which were treated with $40 \mu \mathrm{g} / \mathrm{cm}^{2}$ quartz for 0.5 to 24 hours. ${ }^{*} P<0.05$ and ${ }^{* *} P<0.01$ vs. control. 
A.

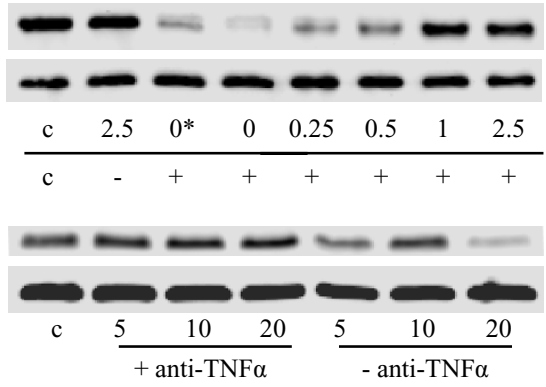

B.

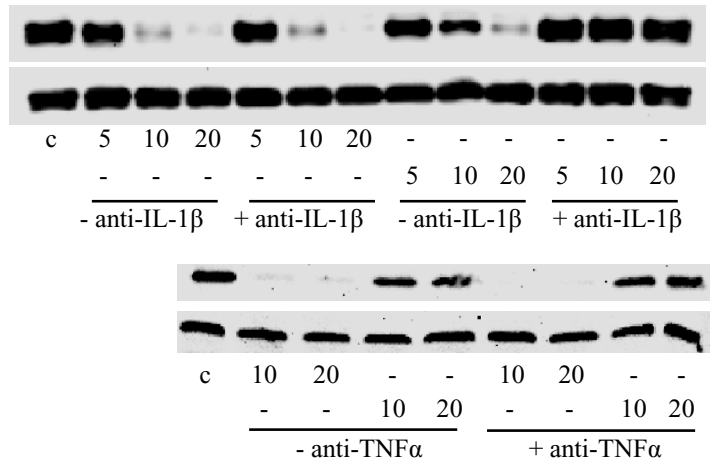

C.

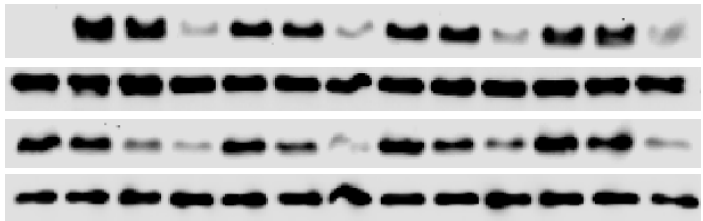

c
$\mathrm{I} \kappa \mathrm{B} \alpha$

$\beta$-tubulin

anti-IL-1 $\beta(\mu \mathrm{g} / \mathrm{ml})$

$1 \mathrm{ng} / \mathrm{ml}$ IL-1 $(10 \mathrm{~min})$

$\mathrm{I} \kappa \mathrm{B} \alpha$

$\beta$-tubulin

$1 \mathrm{ng} / \mathrm{ml} \mathrm{TNF} \alpha(\min )$

$\mathrm{I} \kappa \mathrm{B} \alpha$

$\beta$-tubulin

Q-MS (min)

$0.5 \mathrm{ng} / \mathrm{ml}$ IL $1 \beta(\mathrm{min})$

$\mathrm{I} \kappa \mathrm{B} \alpha$

$\beta$-tubulin

Q-MS (min)

c-MS (min)

$\mathrm{p}$-IкB $\alpha$

$\beta$-tubulin

$\mathrm{I} \kappa \mathrm{B} \alpha$

$\beta$-tubulin

Q-MS (min)

$+2.5 \mathrm{\mu g} / \mathrm{ml}$ anti-IL-1 $\beta$

$+5 \mu \mathrm{g} / \mathrm{ml}$ anti-TNF

D.

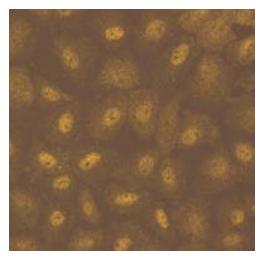

$\mathrm{TNF} \alpha+\mathrm{IL}-1 \beta$

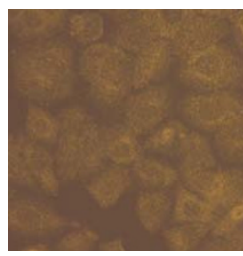

$\mathrm{TNF} \alpha+\mathrm{IL}-1 \beta$

+ anti-TNFa

+ anti-IL-1 $\beta$

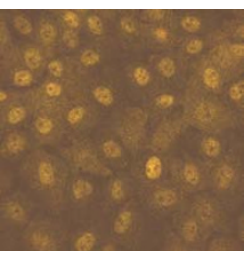

Q-MS

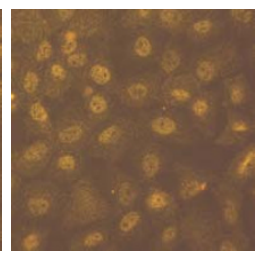

Q-MS

+ anti-TNFa

+ anti-IL-1 $\beta$

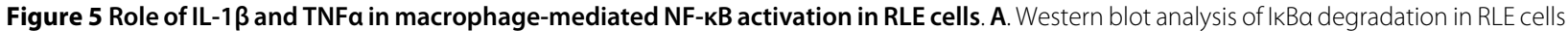
treated with $1 \mathrm{ng} / \mathrm{ml} \mathrm{IL-1 \beta}$ for $10 \mathrm{~min}$ or with $1 \mathrm{ng} / \mathrm{ml}$ TNFa for 5, 10 and $20 \mathrm{~min}$, both pre-treated with neutralising antibodies. For neutralisation, the cytokine solution was incubated for $1 \mathrm{~h}$ with $0.25-2.5 \mu \mathrm{g} / \mathrm{ml}$ anti-IL-1 $\beta$ or $5 \mu \mathrm{g} / \mathrm{ml}$ anti-TNFa antibody. The asterisk indicates cells treated with IL-1 $\beta$ incubated at $37^{\circ} \mathrm{C}$ for $1 \mathrm{~h}$, to investigate incubation effects. $\beta$-tubulin antibody was used as loading control. B. Expression of IkBa protein in RLE cells after treatment with supernatants of quartz-treated $\left(40 \mu \mathrm{g} / \mathrm{cm}^{2}, 24 \mathrm{~h}\right)$ NR8383 cells (Q-MS), that were pre-treated with neutralising antibodies $(5 \mu \mathrm{g} /$ $\mathrm{ml}$ anti-TNFa or $2.5 \mathrm{\mu g} / \mathrm{ml}$ anti-IL-1 $\beta$ ). Supernatant of non-treated (medium, $24 \mathrm{~h}$ ) macrophages (c-MS) was used as negative control for the TNFa neutralisation, $\beta$-tubulin served as loading control. C. and D. Effect of pre-treatment with both neutralising antibodies on NF-kB activation determined by Western blot (C) (phospho-IKBa, total IKBa) and (D) Immunocytochemistry (RelA). For Western blot experiments, RLE cells were treated for 5 to 20 min with native or cocktail-treated Q-MS. For immunocytochemical analysis, cells were treated with Q-MS or a cytokine mix $(0.125 \mathrm{ng} / \mathrm{ml} \mathrm{lL}-1 \beta+0.25 \mathrm{ng} /$ $\mathrm{ml}$ TNFa) for $15 \mathrm{~min}$. Macrophages were treated with $40 \mu \mathrm{g} / \mathrm{cm}^{2}$ DQ12 or medium for $24 \mathrm{~h}$. Original magnification: 1000x. Pre-treatment conditions for both methods consisted of $1 \mathrm{~h}$ incubation with both $5 \mu \mathrm{g} / \mathrm{ml}$ anti-TNFa and $2.5 \mu \mathrm{g} / \mathrm{ml}$ anti-IL $1 \beta$. $\beta$-tubulin was used as loading control. 
tive of the intracellular glutathione status, Q-MS treatment caused I $\mathrm{K} B \alpha$ phosphorylation and its subsequent degradation (Fig. 6A). These observations indicate that the intracellular antioxidant status does not modulate NF- $\mathrm{kB}$ activation by macrophage mediators in our model.

\section{ROS do not activate NF-KB in RLE cells}

To investigate the potential role of ROS in Q-MS-induced NF- $\kappa B$ activation in RLE cells, cells were pre-treated with $\mathrm{BSO}$ and NAC as described before. Then, they were treated with $50 \mu \mathrm{M} \mathrm{H}_{2} \mathrm{O}_{2}$ in $\mathrm{HBSS} . \mathrm{H}_{2} \mathrm{O}_{2}$ failed to activate $\mathrm{NF}-\kappa \mathrm{B}$ in the RLE cells, as there was no visible $\mathrm{I} \kappa \mathrm{B} \alpha$ Ser32/36 phosphorylation, IkB $\alpha$ degradation (Fig. 6B) or increased RelA-DNA-binding activity (data not shown).

\section{Contrasting induction of iNOS, COX-2 and HO-1 mRNA by Q-MS and quartz}

To investigate and compare the effect of quartz and QMS on NF- $\mathrm{KB}$ activation in RLE cells at the mRNA level, cells were treated with quartz and Q-MS for 2, 4 and $8 \mathrm{~h}$, subsequently gene transcripts of the NF-kB-regulated genes inos and cox-2 were measured using qRT-PCR analysis. c-MS served as negative control. Q-MS was capable of strongly and rapidly inducing iNOS, as shown by an over 1300 -fold increase after $2 \mathrm{~h}$, that faded quickly at later time points. Direct treatment of the epithelial cells with quartz elicited a gradual increase, reaching a maximum of 40 -fold after $8 \mathrm{~h}$ (Fig. 7A). COX-2 was induced at all time points by quartz up to 125 -fold after 4

A.

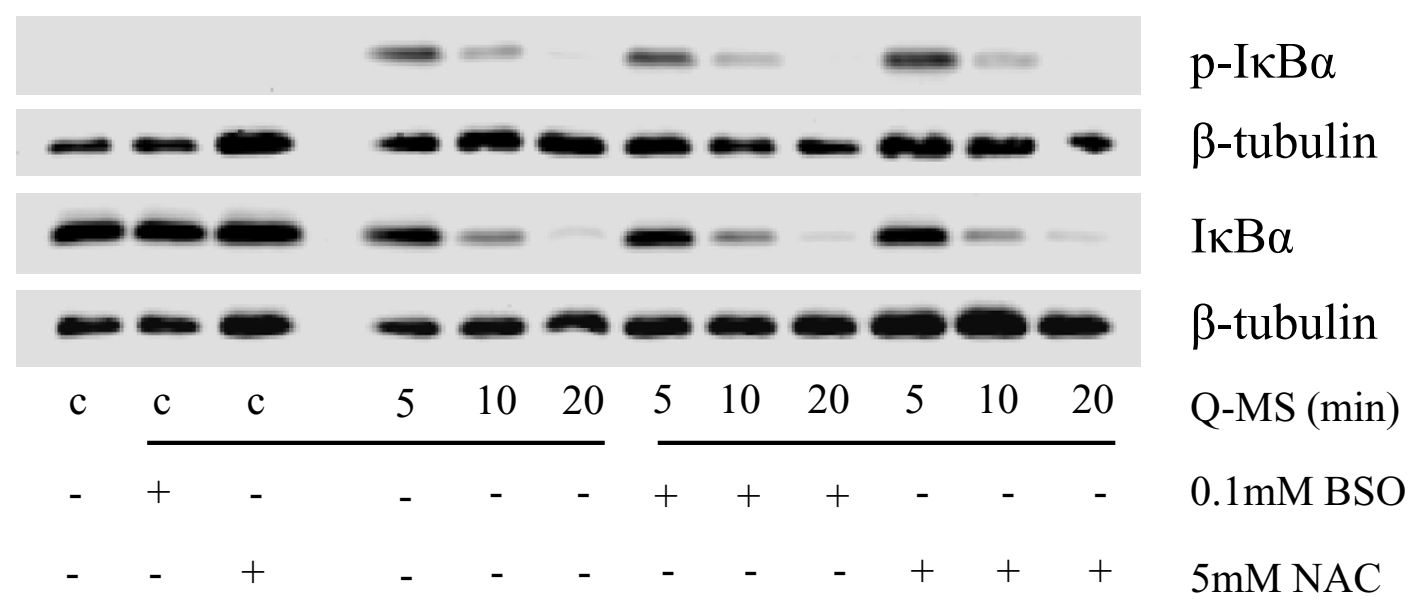

B.

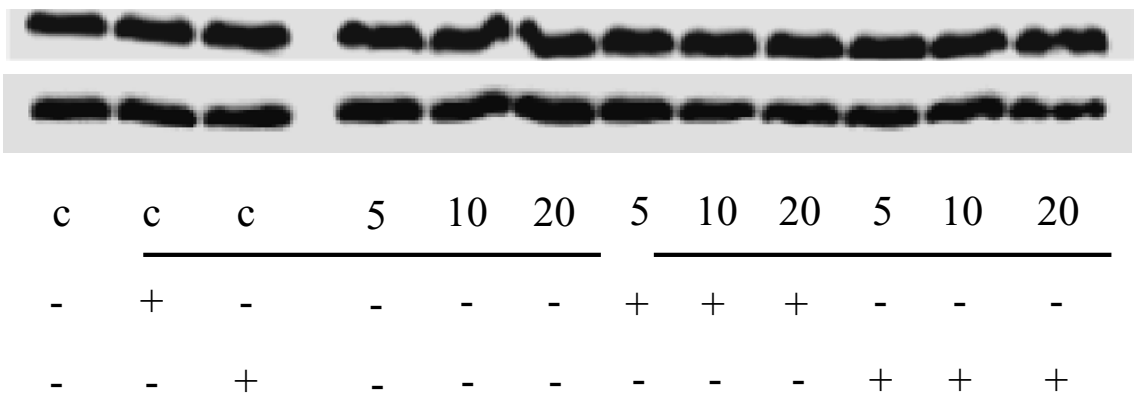

$\mathrm{I} \kappa \mathrm{B} \alpha$

$\beta$-tubulin

$\mathrm{H}_{2} \mathrm{O}_{2}$ (min)

$0.1 \mathrm{mM}$ BSO

$5 \mathrm{mM}$ NAC

Figure 6 Role of ROS and cellular glutathione status in macrophage-mediated NF-KB activation in RLE cells. A. Modulation of intracellular glutathione levels to investigate the influence of intracellular redox status on phosphorylation and degradation of $\mid k B a$ induced by supernatant of quartztreated macrophages (Q-MS). Macrophages were treated with $40 \mu \mathrm{g} / \mathrm{cm}^{2} \mathrm{DQ} 12$ or PBS for $24 \mathrm{~h}$. RLE cells were pretreated with $0.1 \mathrm{mM}$ buthionine sulfoximine (BSO) for $24 \mathrm{~h}$ to deplete glutathione or with $1 \mathrm{mM} \mathrm{N}$-acetyl cysteine (NAC) for $2 \mathrm{~h}$ to enhance intracellular levels. I kBa and phospho-IKBa protein was visualized using Western blot; blots have been reprobed for $\beta$-tubulin as a loading control. B. Investigation of the direct potential of ROS to activate the classical NF-KB pathway by measuring IKBa degradation using Western blotting. RLE cells were treated with $50 \mu \mathrm{M}$ hydrogen peroxide $\left(\mathrm{H}_{2} \mathrm{O}_{2}\right)$ in a medium-free environment for 5-20 min. Additionally, the intracellular glutathione level was modulated using BSO and NAC at concentrations of $0.1 \mathrm{mM}$ and $1 \mathrm{mM}$. $\beta$-tubulin served as loading control. 
A.

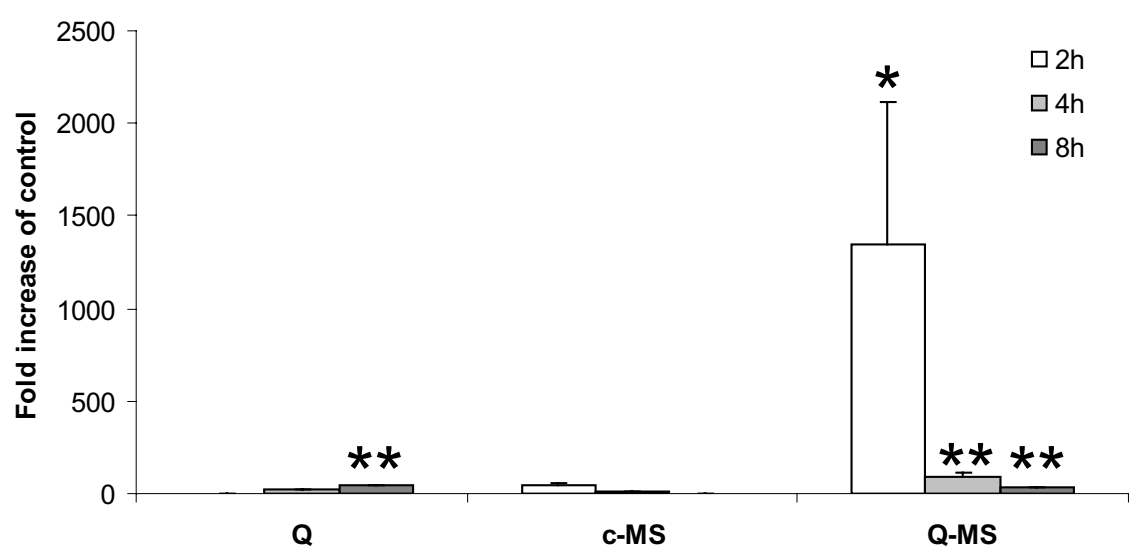

B.

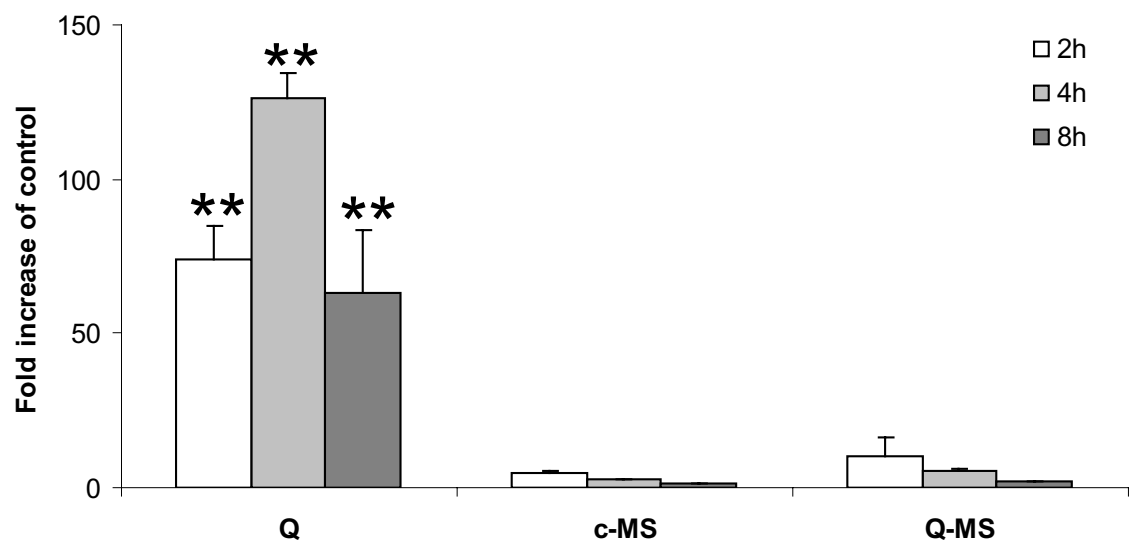

C.

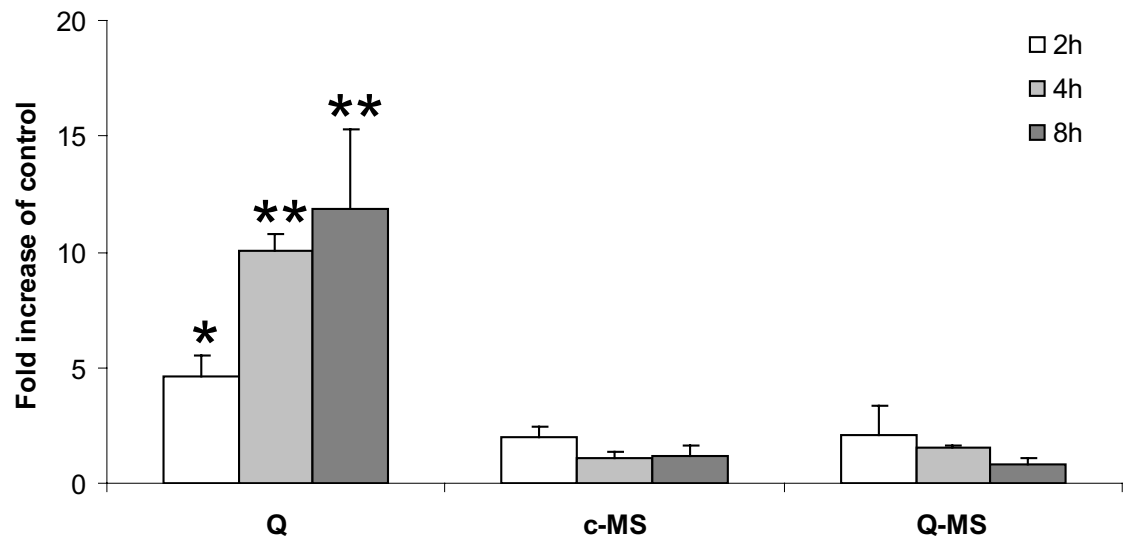

Figure 7 Direct and indirect quartz effects on iNOS, COX-2 and HO-1 mRNA expression in RLE cells. Quantitative RT-PCR determination of mRNA levels of iNOS (A), COX-2 (B) and HO-1 (C) in RLE cells after treatment with quartz (Q) and supernatants of quartz-treated macrophages (Q-MS) for 2,4 or $8 \mathrm{~h}$. As an extra control, cells were additionally treated with supernatants of non-treated macrophages (c-MS). Data are expressed as fold increase of mRNA levels in non-treated control cells and were corrected for the housekeeping gene $\beta$-actin. ${ }^{*} P<0.05$ and ${ }^{* *} P<0.01 \mathrm{vs}$. control. 
h, while Q-MS was a fast but relatively weak inducer of COX-2, peaking at a 10-fold increase after $2 \mathrm{~h}$ (Fig. 7B).

To investigate the observed effects in relation to oxidative stress, transcript levels of $\mathrm{HO}-1$ were measured using the same method. Quartz induced a time-dependent increase of up to 12-fold, while no indirect quartz effect was found in the supernatant-treated cells (Fig. 7C). The qRT-PCR data obtained in this study indicate that iNOS, which was shown to be upregulated in vivo in the rat lung after quartz exposure, can be highly induced in rat lung epithelial cells by products of quartz-treated macrophages, while to a lesser degree and via more gradual kinetics by quartz. In sharp contrast to these findings, COX-2 mRNA was mainly increased by direct quartz treatment. Analysis of HO-1 mRNA demonstrated that only quartz and not Q-MS induces oxidative stress in rat lung epithelial cells.

\section{Pre-coating quartz with PVNO fully inhibits proinflammatory effects of Q-MS and quartz particles}

As inhibition at the macrophage product level proved to be ineffective, an intervention upstream of the proinflammatory activation cascade was performed by modifying the quartz surface with polyvinyl pyridine $\mathrm{N}$-oxide (PVNO). Treatment of RLE cells with supernatant of macrophages treated for $24 \mathrm{~h}$ with $40 \mu \mathrm{g} / \mathrm{cm}^{2} \mathrm{DQ} 12-\mathrm{H}_{2} \mathrm{O}$, a non-coated quartz sample prepared in the same way as PVNO-coated quartz, resulted in a clear IкB $\alpha$ phosphorylation and degradation after 5 - $20 \mathrm{~min}$ (Fig. 8A). Also, the iNOS transcription was strongly induced after $2 \mathrm{~h}$ as seen before using standard Q-MS. When cells were treated with PVNO-Q-MS however, ІкB $\alpha$ phosphorylation and degradation were not visible and induction of iNOS mRNA was nearly abrogated (Fig. 8B). Also, induction of COX-2 expression by Q-MS was all but eliminated by PVNO coating (Fig. 8). Investigation of the direct particle effect of PVNO-quartz on COX-2 and HO-1 expression showed a similar trend: induction of the transcription of both genes was powerfully inhibited (Fig. $8 \mathrm{D}, \mathrm{E})$. These combined findings suggest that PVNO coating of quartz provides effective protection against: (1) macrophage mediated, NF-kB-dependent activation, as well as (2) direct, NF- $k B$-independent, activation of inflammatory mediators in lung epithelium.

\section{Discussion}

The present study was undertaken to address the mechanisms of NF- $\mathrm{KB}$ activation in lung epithelium by respirable quartz particles. In a previous study, we could already show that quartz exposure leads to an increased nuclear staining of the NF- $\kappa B$ subunit RelA in type II epithelial cells as well as alveolar macrophages [21]. Now, we have provided further in vivo evidence for the actual activation of the classical NF- $\mathrm{kB}$ pathway in both cell types, the pathway involving phosphorylation of IкB $\alpha$ at serines 32/ 36 , tagging this inhibitor protein for degradation. In our in vivo model, the observed activation of NF- $\mathrm{kB}$ in rat lung tissue was accompanied by increased mRNA expression of iNOS, which has been shown to be involved in inflammation $[14,17]$ and to be induced on the mRNA level by silica exposure in rat lung [30]. iNOS is known to be regulated at least partly by NF- $\mathrm{kB}$ [31-34]. A classic pro-inflammatory gene induced by NF- $\mathrm{KB}$ is $\mathrm{COX}-2$, known to occupy an important position in the regulation of pulmonary inflammation [35]. Although the role of COX-2 in inflammation is complex and the concept of a general pro-inflammatory role has been disproved [36], in the acute stage of pulmonary disease COX-2 expression is considered to promote inflammation [35]. COX-2 is known to be mainly regulated on the level of transcription [35] and the gene has been shown to be induced in lung epithelial type II cells [37]. In the current study, COX-2 was not significantly induced in vivo following quartz exposure on the mRNA level. In contrast, we observed a significant increase of HO-1 mRNA expression in quartz exposed rat lungs. $\mathrm{HO}-1$ induction is considered as a sensitive oxidative stress marker [38] and has been shown to be increased in serum of silicotic patients as well as in lung tissue of silica-exposed mice $[39,40]$. Our findings provide further support for the well-known role of oxidative stress in silica-elicited pathogenesis $[15,16]$.

Our parallel in vitro approach focused on the investigation of the role of macrophages in NF- $\mathrm{kB}$ activation in lung epithelial cells. Therefore, we compared epithelial NF- $\mathrm{KB}$ activation in response to treatment with cell-free supernatants from quartz-treated macrophages to the direct treatment with quartz particles. Evaluation of NF$\kappa \mathrm{B}$ pathway activation on multiple levels is necessary, as there might be different mechanisms involved. While cytokines like TNF $\alpha$ and IL-1 $\beta$ induce the canonical pathway characterized by IкB $\alpha$ Ser32/36-phosphorylation and degradation, quartz particles have also been shown to activate NF- $\mathrm{kB}$ in macrophages via tyrosine

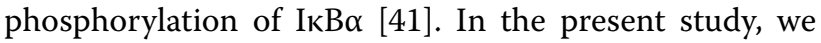
observed that supernatants of quartz-treated NR8383 alveolar macrophages caused Ser32/36 phosphorylation and degradation of $\mathrm{I} \kappa \mathrm{B} \alpha$, the main NF- $\mathrm{kB}$ inhibitor protein, in epithelial cells. These supernatants were also found to cause nuclear translocation and DNA binding of the RelA NF- $\kappa B$ subunit, part of the most common RelAp50 heterodimer that is generally known as NF-kB. Only RelA contains a transactivation domain and thus induces transcription of inflammatory genes [42], while p50 homodimers are known to inhibit transcription by competing for and blocking available DNA docking sites [43]. In association with NF- $\mathrm{kB}$ pathway activation, supernatants from the quartz-treated macrophages also caused a 
A.

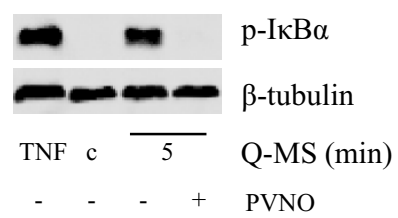

B.
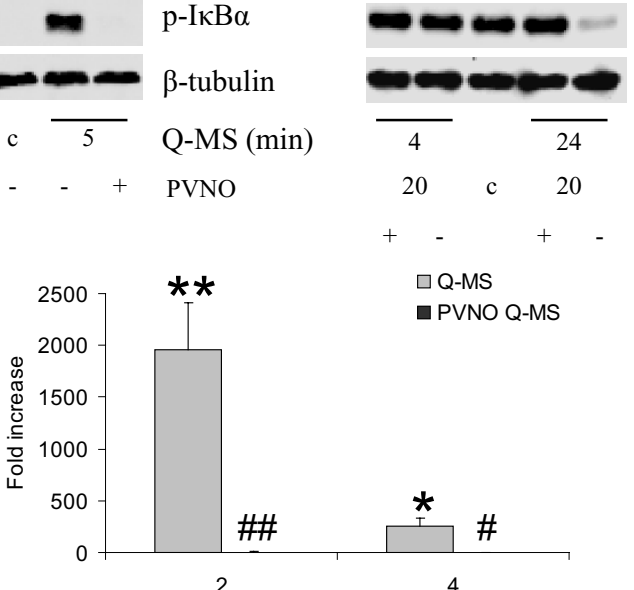

$\mathrm{I} \kappa \mathrm{B} \alpha$

$\beta$-tubulin

Q NR (h)

20 c 20

Q-MS RLE (min)

$+$

$\square \mathrm{Q}-\mathrm{MS}$

a PVNO Q-MS

C.

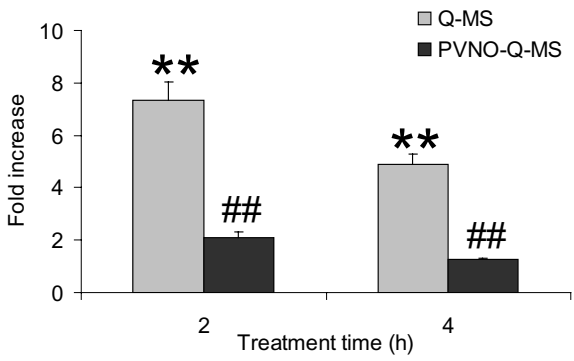

D.

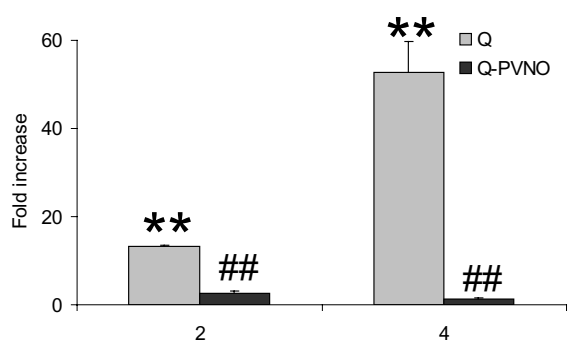

E.

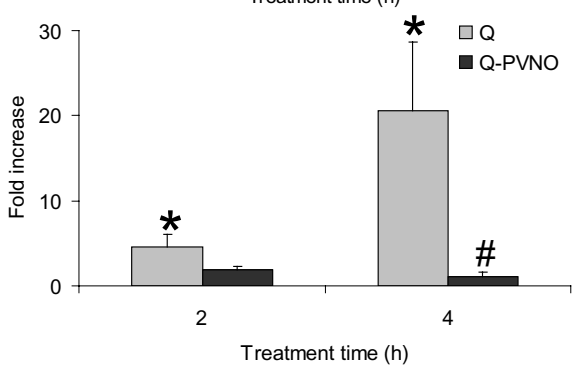

Figure 8 Effects of quartz particle surface modification on NF-kB activation and mRNA expression in RLE cells. A. Western blot analysis of Ser32/36 phospho-IKBa and total IkBa expression in RLE cells treated for 20 min with supernatants of macrophages (Q-MS RLE) that were treated either with native quartz or PVNO-modified quartz for $24 \mathrm{~h}$ (Q-NR). For phospho-IkBa analysis, TNFa ( $10 \mathrm{ng} / \mathrm{ml}, 10 \mathrm{~min})$ was used as positive control. As loading control, blots were reprobed with an antibody against $\beta$-tubulin. B and C. Comparison of mRNA levels of iNOS (B), and COX-2 (C) in RLE cells treated with supernatant of macrophages treated with native quartz (Q-MS) or macrophages treated with PVNO-coated quartz (PVNO Q-MS) for $2 \mathrm{~h}$ and 4 $h$, measured using quantitative RT-PCR. Data are expressed as the fold increase of control mRNA levels and were corrected for the housekeeping gene $\beta$-actin. D and E. Comparison of mRNA levels of COX-2 (D), and HO-1 (E) in RLE cells treated with $40 \mathrm{\mu g} / \mathrm{cm}^{2}$ quartz (Q) or $40 \mu \mathrm{g} / \mathrm{cm}^{2} \mathrm{PVNO}-\mathrm{coated}$ quartz (Q-PVNO) for 2 or $4 \mathrm{~h}$, measured using quantitative RT-PCR determination. Data are expressed as the fold increase of control mRNA levels and were corrected for the housekeeping gene $\beta$-actin. ${ }^{*} P<0.05$ and ${ }^{* *} P<0.01$ vs. control, ${ }^{*} P<0.05$ and \#\# $P<0.01$ vs. Q-MS (panel A, B) or vs. Q (panel C, D). 
massive increase in the number of iNOS gene transcripts in the RLE rat lung epithelial cells. In sharp contrast to these findings, direct treatment with quartz only induced a marginal reduction of IкB $\alpha$ levels after the longest treatment. Apart from reflecting active degradation, the observed IкB $\alpha$ decline may also be a result of an inhibited de novo synthesis [44]. In association with this, quartz itself was also found to be a rather weak inducer of iNOS, when compared to supernatants of the quartz-treated macrophages. However, direct treatment with quartz resulted in a more than 100-fold upregulation of COX-2 mRNA in the RLE cells, an effect that was much stronger than that observed with the macrophage supernatants. An NF- $\mathrm{kB}$-independent induction of COX-2 by silica appears to contrast with previous findings by Choi and colleagues [45]. However, in their study fibroblasts were used, and cell type-specific differences in COX-2 regulation are a possibility. Although COX-2 expression is considered to be regulated through NF- $\mathrm{kB}$ signalling, other transcription factors have been implicated as well, both in general [46,47] and specifically after silica treatment [48]. For instance, in lung epithelial cells, it has been shown that zinc-induced COX-2 induction is not reduced by NF- $\kappa B$ inhibition [49].

To further investigate the mechanism of NF- $\mathrm{kB}$ activation in the lung epithelial cells, we evaluated the roles of the most likely relevant candidates, i.e. the pro-inflammatory cytokines TNF $\alpha$ and IL-1 $\beta$, as well as the involvement of ROS. TNF $\alpha$ and IL- $1 \beta$ are considered important factors in the development of silicosis [12-14] and are well-known inducers of NF-KB in various cell types [811]. Both cytokines were produced by the NR8383 cells upon quartz treatment, and the concentrations as measured in the supernatants of macrophage treated with quartz for various periods matched well with the ability of these supernatants to activate NF- $\mathrm{kB}$. Remarkably however, inhibition of TNF $\alpha$ or IL- $1 \beta$ with their respective neutralizing antibodies did not influence NF- $\mathrm{kB}$-inducing potential of the supernatants from quartz-treated NR8383 cells. Even when both cytokines were neutralized simultaneously in the supernatants from the quartztreated macrophages, epithelial NF- $\mathrm{KB}$ activation could not be inhibited. Taken together, these findings suggest that neither TNF $\alpha$ nor IL- $1 \beta$ plays a crucial role in quartz-induced NF- $\mathrm{\kappa B}$ activation in lung epithelial cells, and that other factors are at least involved or possibly even more important. This is in accordance with previous investigations in our laboratory, which indicated that in vivo NF- $\mathrm{kB}$ activation by quartz may be, at least in part, TNF $\alpha$-independent [21].

To address the potential role of ROS in the macrophage-mediated NF- $\mathrm{kB}$ activation in RLE cells the effects of $\mathrm{H}_{2} \mathrm{O}_{2}$, BSO and NAC were evaluated. $\mathrm{An}_{2} \mathrm{H}_{2}$ concentration of $50 \mu \mathrm{M}$ was used, as it was shown to induce a strong increase in NF- $\mathrm{KB}$ DNA binding activity in Jurkat cells [19], while in addition, in our lab it proved to be one of the highest concentrations applicable without causing significant cytotoxicity in RLE cells (data not shown). $\mathrm{H}_{2} \mathrm{O}_{2}$ is well known to possess NF- $\mathrm{kB}$ activating properties, albeit in a cell specific-manner $[19,50] . \mathrm{H}_{2} \mathrm{O}_{2}$ is formed upon the dismutation of superoxide anions which are generated in large amounts by activated macrophages during inflammation. Although the generation of ROS from DQ12-treated NR8383 macrophages was shown in this study in a concentration and time dependent manner, $\mathrm{H}_{2} \mathrm{O}_{2}$ treatment did not lead to any notable Iк $\mathrm{B} \alpha$ degradation in the RLE cells. This observation might be due to the fact that $\mathrm{H}_{2} \mathrm{O}_{2}$ has been found to activate NF- $\kappa B$ through a non-classical pathway in some cell types, involving tyrosine phosphorylation of IкB $\alpha$ and direct activation of RelA [51]. However, nuclear extracts from $\mathrm{H}_{2} \mathrm{O}_{2}$ treated RLE cells failed to increase DNA binding activity of RelA in our hands (data not shown). In line with these observations, we also did not observe any effect of the macrophage supernatants on NF- $\mathrm{kB}$ pathway activation in RLE cells upon modification of the intracellular glutathione content with BSO or NAC. In alveolar epithelial cells, glutathione is considered to be the most important intracellular antioxidant [52]. Lower levels of intracellular glutathione have been associated with enhanced NF- $\mathrm{kB}$ activation [53]. In Jurkat cells, increasing intracellular glutathione levels using $\mathrm{NAC}$ has been shown to block $\mathrm{H}_{2} \mathrm{O}_{2}$-induced NF-kB activation [19]. There is also evidence for the interplay between ROS and cytokines in NF- $\mathrm{kB}$ induction [18]. In our hands however, depleting the intracellular glutathione concentration to $5 \%$ of its normal level using $\mathrm{BSO}$ or augmenting it to $133 \%$ using NAC did not influence NF- $\mathrm{KB}$ activation in macrophage supernatant-treated or $\mathrm{H}_{2} \mathrm{O}_{2}$-treated RLE cells. It remains to be investigated whether in our experiments the protective role of glutathione is taken over by other intracellular thiols or thioredoxin [54].

Our findings suggest that oxidative stress is not a key mechanism in the activation of NF- $\mathrm{KB}$ in lung epithelial cells by quartz. This is evidenced by the inability of $\mathrm{H}_{2} \mathrm{O}_{2}$ to directly activate NF- $\mathrm{kB}$, as well as the finding that modulation of the intracellular antioxidant level did not influence classical NF- $\kappa B$ pathway activation. As ROS are highly reactive and extremely short-lived, stronger proof for this concept might be obtained from future in vitro co-culture experiments where macrophages and type II epithelial cells are cultured simultaneously, so that macrophages are allowed to adhere to lung epithelial cells, providing an oxidative stress setting more similar to the in vivo situation. In a mixed co-culture of primary rat macrophages and primary epithelial type II cells however, no significant induction of several proinflammatory 
genes, including iNOS, was found after silica treatment [55]. The discrepancy between these investigations and the current study might be due to the different experimental set-up. Although primary cells are of higher biological relevance, the isolation of these cells might induce stress-related genes in the cells, which could make it harder to observe differences between treated and control cells. Another possibility is that direct contact of macrophages and epithelial cells diminishes iNOS induction by quartz treatment, possibly due to a lower activation of macrophages by surfactant production, which was shown in a follow-up to the former study [56].

In previous studies, we have demonstrated that modification of the surface of DQ12 quartz particles, e.g. using the polymer PVNO, leads to a marked inhibition of inflammation and toxicity in rat lungs after instillation $[21,24,57]$. In the present study, we found marked effects of particle surface modification in our in vitro model: When cells were treated with supernatant from PVNOquartz-treated macrophages, I $\mathrm{B} \alpha$ phosphorylation and degradation was abolished, compared to the effect of supernatants obtained from macrophages that were treated with the non-coated quartz. Also, the induction of the two main genes induced by macrophage supernatants in our system, iNOS and COX-2, was found to be abrogated. A similar inhibition was found for direct quartz treatment, as HO-1 and COX-2 induction was almost brought back to the control level. Our current findings with the PVNO-modified particles point towards a specific effect of quartz particles, and suggest that particles of lower toxicity or reactivity may not trigger either the macrophage-driven or direct particulate effects on the epithelial cells. Currently we are investigating this by evaluating a set of particle types with different size and surface properties. Altogether our study indicates the existence of a differentially mediated proinflammatory activation of lung epithelial cells in quartzexposed lung, which in both cases appears to be driven by the particle surface properties: Firstly, quartz particles can induce cellular oxidative stress leading to an NF- $\mathrm{kB}$ independent increase in expression of $\mathrm{HO}-1$ and $\mathrm{COX}-2$. We hypothesise that the transcription factor nuclear factor E2-related factor 2 (nrf-2), which was elegantly shown to be the main transcription factor regulating $\mathrm{HO}-1$ expression [58], is at least in part involved in these observed direct quartz effects. Secondly, stable mediators released from quartz-treated macrophages strongly induce the classical NF- $\mathrm{kB}$ pathway as well as iNOS. Remarkably, the involvement of the most likely candidates for this indirect, macrophage-mediated activation, i.e. TNF $\alpha$, IL-1 $\beta$ and $\mathrm{H}_{2} \mathrm{O}_{2}$ could be ruled out. In further experiments we could also exclude potential contributions of macrophage-derived NO as well as of proteases, which both have been shown to be involved in activation of the NF-kB pathway $[59,60]$. In line with observations by others who have used primary macrophages [61], quartz did not elicit any detectable NO production from quartz-treated NR8383 cells, measured using the Griess assay, in contrast to lipopolysaccharide (LPS, 0.1 or $1 \mathrm{~g} / \mathrm{l}$ ) (data not shown). The effect of proteases could be ruled out by the addition of protease inhibitors to the supernatants of quartz-treated NR8383 cells (data not shown). Among various potential candidates, one could also consider prostaglandins (PG), which are known to be released from macrophages. However, there is considerable experimental data suggesting that many of the arachidonic acid metabolites rather act as NF- $\mathrm{kB}$ inhibitors and thereby provide a negative feedback loop for COX-2 expression [62,63]. Indeed, the well investigated metabolite PGE2, which is considered as an acute proinflammatory mediator, has been shown to increase the transactivation potential of the RelA subunit of NF- $\mathrm{KB}$ in intestinal epithelial cell lines. However, this effect was demonstrated to occur in the absence of IкB $\alpha$ degradation and nuclear accumulation of NF-KB [62]. Thus, macrophage-derived prostaglandins including PGE2, unlikely explain for the observed macrophage-mediated phosphorylation and degradation of IкB $\alpha$ and subsequent translocation of RelA in the RLE cells. Although the responsible mechanism is yet to be identified, our data indicate that for therapeutic or possible preventive approaches, an intervention at the macrophage product level might not be feasible, as targeting of the main individual mediators suspected to be involved (TNF $\alpha$, IL-1 $\beta$ ) was unsuccessful. Additionally, in such intervention direct particle effects on epithelial cells (e.g. COX-2 induction) would persist. Instead, a more promising strategy should focus on upstream processes, e.g. by targeting the initial activation of macrophages by the quartz particles. Preferentially, one should aim at blocking the secretion of mediators from macrophages without interfering with their phagocytic properties that are essential for lung homeostasis and are known to provide the hallmark of particle clearance out of the alveoli via the lymph nodes. Recent in vitro investigations in our laboratory [64] indicate that this may possibly be achieved by targeting Fc II-receptor signalling pathway in the macrophages.

\section{Conclusions}

The data presented in the current paper show, on the one hand, that macrophage products secreted in response to quartz treatment induce NF- $\mathrm{KB}$ and iNOS in rat alveolar type II epithelial cells, unlike the quartz particles themselves. On the other hand, the particles, rather than macrophage mediators, markedly induce $\mathrm{HO}-1$ and $\mathrm{COX}-2$ mRNA expression in epithelial cells in the absence of NF$\kappa \mathrm{B}$ pathway activation. Taken together, our results suggest that although both oxidative stress and NF- $\mathrm{kB}$ are 
likely involved in the inflammatory effects of toxic respirable particles, these phenomena can operate independently on the cellular level. This indicates that in vitro testing strategies to predict the inflammogenic potency of particles should not exclusively target the NF- $\mathrm{KB}$ pathway. Our findings also underscore the importance of further elucidation on the involvement of NF-kBindependent signalling pathways in the development and progression of pulmonary disorders induced by toxic particles such as quartz.

\begin{abstract}
Abbreviations
DQ12: Dörentrup Quartz "ground product nr. 12"; Q: quartz particles, see above; PVNO: Polyvinylpyridine N-oxide; Q-MS: supernatant of quartz-treated macrophages; c-MS: supernatant of non-treated control macrophages; ROS Reactive Oxygen Species; TNFa: Tumour Necrosis Factor alpha; IL-1B: Interleukin-1 beta; HO-1: Heme Oxygenase-1; iNOS: inducible Nitric Oxide Synthase; COX-2: Cyclooxygenase-2; COPD: Chronic Obstructive Pulmonary Disease; AM: Alveolar Macrophage; RNS: Reactive Nitrogen Species; NF-kB: Nuclear Factor kappa-B; IkBa: Inhibitor of kB alpha; BAL: Bronchoalveolar Lavage; BSO: Buthionine Sulfoximine; NAC: N-acetyl cysteine; DMSO: dimethylsulfoxide; HBSS: Hanks' Buffered Salt Solution; DMPO: 5,5-Dimethyl-1-pyrroline N-oxide; DMPO$\mathrm{OH}$ : 5,5-Dimethyl-1-pyrroline $\mathrm{N}$-oxide hydroxide.
\end{abstract}

\section{Competing interests}

The authors declare that they have no competing interests.

\section{Authors' contributions}

DvB performed most of the experimental work and drafted the manuscript. AK participated in the RT-PCR work. FvS was involved in the study coordination and the RT-PCR analyses. RS was involved in the study design and coordination and helped drafting the manuscript. CA was involved in the study design and coordination, performed the animal experimental work, assisted in the immunocyto- and -histochemistry and helped drafting the manuscript. All authors read, commented on and approved the manuscript.

\section{Acknowledgements}

This work was supported by a grant from the German Federal Ministry of the Environment (BMU). The authors would like to thank Dr. Klaus Unfried for assisting in the animal instillation experiments.

\section{Author Details}

${ }^{1}$ Institut für Umweltmedizinische Forschung (IUF) an der Heinrich-HeineUniversität Düsseldorf gGmbH, Germany, ${ }^{2}$ Department of Health Risk Analysis and Toxicology, Maastricht University, the Netherlands and ${ }^{3}$ Department of Toxicology and Drug Disposition, Schering-Plough, the Netherlands

Received: 9 February 2010 Accepted: 21 May 2010

Published: 21 May 2010

\section{References}

1. Steenland K, Sanderson W: Lung cancer among industrial sand workers exposed to crystalline silica. Am J Epidemiol 2001, 153(7):695-703.

2. Steenland K, Mannetje A, Boffetta P, Stayner L, Attfield M, Chen J, Dosemeci M, DeKlerk N, Hnizdo E, Koskela R, Checkoway H, International Agency for Research on Cancer: Pooled exposure-response analyses and risk assessment for lung cancer in 10 cohorts of silica-exposed workers: an IARC multicentre study. Cancer Causes Control 2001, 12(9):773-784

3. Kuempel ED, Attfield MD, Vallyathan V, Lapp NL, Hale JM, Smith RJ Castranova V: Pulmonary inflammation and crystalline silica in respirable coal mine dust: dose-response. J Biosci 2003, 28(1):61-69.

4. Driscoll KE, Lindenschmid RC, Maurer JK, Higgins JM, Ridder G: Pulmonary response to silica or titanium dioxide: inflammatory cells, alveolar macrophage-derived cytokines, and histopathology. Am J Respir Cell Mol Biol 1990, 2:381-390.

5. Driscoll KE: Role of inflammation in the development of rat lung tumors in response to chronic particle exposure. Inhal Toxicol 1996, 8:139-153.
6. Chen F, Shi X: NF-kappaB, a pivotal transcription factor in silica-induced diseases. Mol Cell Biochem 2002, 234-235(1-2):169-176.

7. Schins RPF, Donaldson K: Nuclear factor kappa-B activation by particles and fibres. Inhal Toxicol 2000, 12(3):317-326.

8. Osborn L, Kunkel S, Nabel GJ: Tumor necrosis factor alpha and interleukin 1 stimulate the human immunodeficiency virus enhancer by activation of the nuclear factor kappa B. Proc Natl Acad Sci USA 1989, 86(7):2336-2340.

9. Piguet PF, Collart MA, Grau GE, Sappino AP, Vassalli P: Requirement of tumour necrosis factor for development of silica-induced pulmonary fibrosis. Nature 1990, 344(6263):245-247.

10. Kida Y, Kobayashi M, Suzuki T, Takeshita A, Okamatsu Y, Hanazawa S, Yasui T, Hasegawa K: Interleukin-1 stimulates cytokines, prostaglandin E2 and matrix metalloproteinase-1 production via activation of MAPK/AP-1 and NF-kappaB in human gingival fibroblasts. Cytokine 2005 , 29(4):159-168.

11. Israel A, Le Bail O, Hatat D, Piette J, Kieran M, Logeat F, Wallach D, Fellous $M$, Kourilsky P: TNF stimulates expression of mouse MHC class I genes by inducing an NF kappa B-like enhancer binding activity which displaces constitutive factors. EMBO J 1989, 8(12):3793-3800.

12. Dubois CM, Bissonnette $E$, Rola-Pleszczynski M: Asbestos fibers and silica particles stimulate rat alveolar macrophages to release tumor necrosis factor. Autoregulatory role of leukotriene B4. Am Rev Respir Dis 1989, 139(5):1257-1264.

13. Davis GS, Pfeiffer LM, Hemenway DR: Persistent overexpression of interleukin-1 beta and tumor necrosis factor-alpha in murine silicosis. $J$ Environ Pathol Toxicol Oncol 1998, 17(2):99-114.

14. Srivastava KD, Rom WN, Jagirdar J, Yie TA, Gordon T, Tchou-Wong KM: Crucial role of interleukin-1 beta and nitric oxide synthase in silicainduced inflammation and apoptosis in mice. Am J Respir Crit Care Med 2002, 165(4):527-533.

15. Porter DW, Millecchia L, Robinson VA, Hubbs A, Willard P, Pack D, Ramsey D, McLaurin J, Khan A, Landsittel D, Teass A, Castranova V: Enhanced nitric oxide and reactive oxygen species production and damage after inhalation of silica. Am J Physiol Lung Cell Mol Physiol 2002, 283(2):L485-L493.

16. Castranova $\mathrm{V}$ : Role of nitric oxide in the progression of pneumoconiosis. Biochemistry (Mosc) 2004, 69(1):32-37.

17. Zeidler P, Hubbs A, Battelli L, Castranova V: Role of inducible nitric oxide synthase-derived nitric oxide in silica-induced pulmonary inflammation and fibrosis. J Toxicol Environ Health A 2004, 67(13):1001-1026.

18. Janssen-Heininger YM, Macara I, Mossman BT: Cooperativity between oxidants and tumor necrosis factor in the activation of nuclear factor (NF)-kappaB: requirement of Ras/mitogen-activated protein kinases in the activation of NF-kappaB by oxidants. Am J Respir Cell Mol Biol 1999 20(5):942-952.

19. Schreck R, Rieber $P$, Baeuerle PA: Reactive oxygen intermediates as apparently widely used messengers in the activation of the NF-kappa B transcription factor and HIV-1. EMBO J 1991, 10(8):2247-2258.

20. Duffin R, Gilmour PS, Schins RP, Clouter A, Guy K, Brown DM, MacNee W, Borm PJ, Donaldson K, Stone V: Aluminium lactate treatment of DQ12 quartz inhibits its ability to cause inflammation, chemokine expression, and nuclear factor-kappaB activation. Toxicol Appl Pharmacol 2001, 176(1):10-17.

21. Albrecht C, Schins RP, Höhr D, Becker A, Shi T, Knaapen AM, Borm PJ: Inflammatory time course after quartz instillation: role of tumor necrosis factor-alpha and particle surface. Am J Respir Cell Mol Biol 2004, 31(3):292-301

22. Hubbard AK, Timblin CR, Shukla A, Rincón M, Mossman BT: Activation of NF-kappaB-dependent gene expression by silica in lungs of luciferase reporter mice. Am J Physiol Lung Cell Mol Physiol 2002, 282(5):L968-L975.

23. Cheng DS, Han W, Chen SM, Sherrill TP, Chont M, Park GY, Sheller JR, Polosukhin VV, Christman JW, Yull FE, Blackwell TS: Airway epithelium controls lung inflammation and injury through the NF-kappa B pathway. J Immunol 2007, 178(10):6504-6513.

24. Albrecht $C$, Knaapen AM, Becker A, Höhr D, Haberzettl P, van Schooten FJ, Borm PJ, Schins RP: The crucial role of particle surface reactivity in respirable quartz-induced reactive oxygen/nitrogen species formation and APE/Ref-1 induction in rat lung. Respir Res 2005, 6:129. 
25. Helmke RJ, Boyd RL, German VF, Mangos JA: From growth factor dependence to growth factor responsiveness: the genesis of an alveolar macrophage cell line. In Vitro Cell Dev Biol 1987, 23(8):567-574.

26. Driscoll KE, Carter JM, Iype PT, Kumari HL, Crosby LL, Aardema MJ, Isfort RJ, Cody D, Chestnut MH, Burns JL, LeBoeuf RA: Establishment of immortalized alveolar type II epithelial cell lines from adult rats. In Vitro Cell Dev Biol Anim 1995, 31(7):516-527.

27. Livak KJ, Schmittgen TD: Analysis of relative gene expression data using real-time quantitative PCR and the 2(-Delta Delta C(T)) Method. Methods 2001, 25(4):402-408.

28. Renard P, Ernest I, Houbion A, Art M, Le Calvez H, Raes M, Remacle J: Development of a sensitive multi-well colorimetric assay for active NFkB. Nucleic Acids Res 2001, 29(4):e21.

29. Tietze F: Enzymic method for quantitative determination of nanogram amounts of total and oxidized glutathione: applications to mammalian blood and other tissues. Anal Biochem 1969, 27(3):502-522.

30. Blackford JA, Jones W Jr, Dey RD, Castranova V: Comparison of inducible nitric oxide synthase gene expression and lung inflammation following intratracheal instillation of silica, coal, carbonyl iron, or titanium dioxide in rats. J Toxicol Environ Health 1997, 51(3):203-218.

31. Taylor BS, de Vera ME, Ganster RW, Wang Q, Shapiro RA, Morris SM Jr, Billiar TR, Geller DA: Multiple NF-kappaB enhancer elements regulate cytokine induction of the human inducible nitric oxide synthase gene. J Biol Chem 1998, 273(24):15148-15156.

32. Laskin DL, Sunil V, Guo Y, Heck DE, Laskin JD: Increased nitric oxide synthase in the lung after ozone inhalation is associated with activation of NF-kappa B. Environ Health Perspect 1998, 106(Suppl 5):1175-1178

33. Nunokawa $Y$, Oikawa S, Tanaka S: Human inducible nitric oxide synthase gene is transcriptionally regulated by nuclear factor-kappaB dependent mechanism. Biochem Biophys Res Commun 1996, 223(2):347-352

34. Malladi V, Puthenedam M, Williams PH, Balakrishnan A: Enteropathogenic Escherichia coli outer membrane proteins induce iNOS by activation of NF-kappaB and MAP kinases. Inflammation 2004, 28(6):345-353.

35. Park GY, Christman JW: Involvement of cyclooxygenase-2 and prostaglandins in the molecular pathogenesis of inflammatory lung diseases. Am J Physiol Lung Cell Mol Physiol 2006, 290:L797-L805.

36. Gilroy DW, Colville-Nash PR, Willis D, Chivers J, Paul-Clark MJ, Willoughby DA: Inducible cyclooxygenase may have anti-inflammatory properties. Nat Med 1999, 5:698-701.

37. Li H, van Berlo D, Shi T, Speit G, Knaapen AM, Borm PJ, Albrecht C, Schins RP: Curcumin protects against cytotoxic and inflammatory effects of quartz particles but causes oxidative DNA damage in a rat lung epithelial cell line. Toxicol Appl Pharmacol 2008, 227(1):115-124.

38. Li N, Wang M, Oberley TD, Sempf JM, Nel AE: Comparison of the prooxidative and proinflammatory effects of organic diesel exhaust particle chemicals in bronchial epithelial cells and macrophages. J Immunol 2002, 169(8):4531-4541.

39. Van Berlo D, Wessels A, Boots AW, Wilhelmi V, Scherbart AM, Gerloff K, Albrecht C, Schins RPF: Neutrophil-derived oxygen species contribute to oxidative stress and DNA damage induction by respirable quartz particles. in press.

40. Sato T, Takeno M, Honma K, Yamauchi H, Saito Y, Sasaki T, Morikubo H, Nagashima Y, Takagi S, Yamanaka K, Kaneko T, Ishigatsubo Y: Heme oxygenase-1, a potential biomarker of chronic silicosis, attenuates silica-induced lung injury. Am J Respir Crit Care Med 2006, 174(8):906-914.

41. Kang JL, Pack IS, Hong SM, Lee HS, Castranova V: Silica induces nuclear factor-kappa B activation through tyrosine phosphorylation of I kappa B-alpha in RAW264.7 macrophages. Toxicol Appl Pharmacol 2000, 169(1):59-65

42. Schmitz M, dos Santos Silva MA, Baeuerle PA: Transactivation domain 2 (TA2) of p65 NF-kappa B. Similarity to TA1 and phorbol esterstimulated activity and phosphorylation in intact cells. J Biol Chem 1995, 270:15576-15584

43. Baer M, Dillner A, Schwartz RC, Sedon C, Nedospasov S, Johnson PF: Tumor necrosis factor alpha transcription in macrophages is attenuated by an autocrine factor that preferentially induces NFkappaB p50. Mol Cell Biol 1998, 18(10):5678-5689.

44. Schins RP, McAlinden A, MacNee W, Jimenez LA, Ross JA, Guy K, Faux SP, Donaldson K: Persistent depletion of I kappa B alpha and interleukin-8 expression in human pulmonary epithelial cells exposed to quartz particles. Toxicol Appl Pharmacol 2000, 167(2):107-117.

45. Choi JK, Lee SG, Lee JY, Nam HY, Lee WK, Lee KH, Kim HJ, Lim Y: Silica induces human cyclooxygenase-2 gene expression through the NFkappaB signaling pathway. J Environ Pathol Toxicol Oncol 2005 24(3):163-174

46. Kang YJ, Mbonye UR, DeLong CJ, Wada M, Smith WL: Regulation of intracellular cyclooxygenase levels by gene transcription and protein degradation. Prog Lipid Res 2007, 46(2):108-125.

47. Tsatsanis C, Androulidaki A, Venihaki M, Margioris AN: Signalling networks regulating cyclooxygenase-2. Int J Biochem Cell Biol 2006 , 38(10):1654-1661

48. Scarfi S, Benatti U, Pozzolini M, Clavarino E, Ferraris C, Magnone M, Valisano L, Giovine M: Ascorbic acid-pretreated quartz enhances cyclooxygenase-2 expression in RAW 264.7 murine macrophages. FEBS J 2007, 274(1):60-73.

49. Wu W, Silbajoris RA, Cao D, Bromberg PA, Zhang Q, Peden DB, Samet JM: Regulation of cyclooxygenase- 2 expression by cAMP response element and mRNA stability in a human airway epithelial cell line exposed to zinc. Toxicol Appl Pharmacol 2008, 231(2):260-266.

50. Brennan P, O'Neill LA: Effects of oxidants and antioxidants on nuclear factor kappa B activation in three different cell lines: evidence against a universal hypothesis involving oxygen radicals. Biochim Biophys Acta 1995, 1260(2):167-175.

51. Takada Y, Mukhopadhyay A, Kundu GC, Mahabeleshwar GH, Singh S, Aggarwal BB: Hydrogen peroxide activates NF-kappa B through tyrosine phosphorylation of I kappa $B$ alpha and serine phosphorylation of p65: evidence for the involvement of I kappa $B$ alpha kinase and Syk protein-tyrosine kinase. J Biol Chem 2003, 278(26):24233-24241.

52. Rahman I, Mulier B, Gilmour PS, Watchorn T, Donaldson K, Jeffery PK, MacNee W: Oxidant-mediated lung epithelial cell tolerance: the role of intracellular glutathione and nuclear factor-kappaB. Biochem Pharmacol 2001, 62(6):787-794.

53. Hehner SP, Breitkreutz R, Shubinsky G, Unsoeld H, Schulze-Osthoff K, Schmitz ML, Dröge W: Enhancement of T cell receptor signaling by a mild oxidative shift in the intracellular thiol pool. J Immunol 2000, 165(8):4319-4328.

54. Watson WH, Yang $X$, Choi YE, Jones DP, Kehrer JP: Thioredoxin and its role in toxicology. Toxicol Sci 2004, 78:3-14.

55. Rao KM, Porter DW, Meighan T, Castranova V: The sources of inflammatory mediators in the lung after silica exposure. Environ Health Perspect 2004, 112(17):1679-1686.

56. Kanj RS, Kang JL, Castranova V: Interaction between primary alveolar macrophages and primary alveolar type II cells under basal conditions and after lipopolysaccharide or quartz exposure. J Toxicol Environ Health A 2006, 69(11):1097-1116.

57. Knaapen AM, Albrecht C, Becker A, Höhr D, Winzer A, Haenen GR, Borm PJ, Schins RP: DNA damage in lung epithelial cells isolated from rats exposed to quartz: role of surface reactivity and neutrophilic inflammation. Carcinogenesis 2002, 23(7):1111-1120.

58. Mochizuki M, Ishii Y, Itoh K, lizuka T, Morishima Y, Kimura T, Kiwamoto T, Matsuno Y, Hegab AE, Nomura A, Sakamoto T, Uchida K, Yamamoto M, Sekizawa K: Role of 15 -deoxy delta $(12,14)$ prostaglandin J2 and Nrf2 pathways in protection against acute lung injury. Am J Respir Crit Care Med 2005, 171(11):1260-1266.

59. Kim SJ, Chun JS: Protein kinase C alpha and zeta regulate nitric oxideinduced NF-kappa B activation that mediates cyclooxygenase-2 expression and apoptosis but not dedifferentiation in articular chondrocytes. Biochem Biophys Res Commun 2003, 303(1):206-211.

60. Finco TS, Beg AA, Baldwin AS Jr: Inducible phosphorylation of I kappa B alpha is not sufficient for its dissociation from NF-kappa $B$ and is inhibited by protease inhibitors. Proc Nat/ Acad Sci USA 1994 91(25):11884-11888

61. Huffman $L J$, Judy DJ, Castranova V: Regulation of nitric oxide production by rat alveolar macrophages in response to silica exposure. J Toxicol Environ Health A 1998, 53(1):29-46.

62. Poligone $B$, Baldwin AS: Positive and negative regulation of NF-kappaB by COX-2: roles of different prostaglandins. J Biol Chem 2001, 276(42):38658-38664

63. Gomez PF, Pillinger MH, Attur M, Marjanovic N, Dave M, Park J, Bingham $\mathrm{CO}, \mathrm{Al}-\mathrm{Mussawir} \mathrm{H}$, Abramson SB: Resolution of inflammation: 
prostaglandin E2 dissociates nuclear trafficking of individual NFkappaB subunits $(\mathrm{p} 65, \mathrm{p} 50)$ in stimulated rheumatoid synovial fibroblasts. J Immunol 2005, 175(10):6924-6930.

64. Haberzettl P, Schins RP, Höhr D, Wilhelmi V, Borm PJ, Albrecht C: Impact of the Fcgammall-receptor on quartz uptake and inflammatory response by alveolar macrophages. Am J Physiol Lung Cell Mol Physiol 2008, 294(6):L1137-L1148.

doi: $10.1186 / 1743-8977-7-13$

Cite this article as: van Berlo et al., NF-?B dependent and independent mechanisms of quartz-induced proinflammatory activation of lung epithelial cells Particle and Fibre Toxicology 2010, 7:13

Submit your next manuscript to BioMed Central and take full advantage of:

- Convenient online submission

- Thorough peer review

- No space constraints or color figure charges

- Immediate publication on acceptance

- Inclusion in PubMed, CAS, Scopus and Google Scholar

- Research which is freely available for redistribution

Submit your manuscript at www.biomedcentral.com/submit 